\title{
Revoltas regenciais na Corte: o movimento de 17 de abril de 1832
}

Marcello Basile*

\begin{abstract}
Resumo. Uma das fases mais ricas e singulares em termos de organização, discussão e participação políticas, o Período Regencial (1831-1840), é também o mais agitado e conturbado da história do Brasil. Este artigo analisa uma das principais revoltas então ocorridas no Rio de Janeiro: a que, em 17 de abril de 1832, sacudiu a capital do Império, capitaneada pelos caramurus. Estes constituíam uma facção política surgida logo após a abdicação de Pedro I, essencialmente formada por políticos e cortesãos ligados ao ex-imperador, por antigos funcionários públicos civis e militares e por comerciantes e caixeiros portugueses. Opunham-se eles a qualquer reforma na Constituição de 1824 e defendiam uma monarquia constitucional fortemente centralizada, nos moldes do Primeiro Reinado, chegando, em casos excepcionais, a nutrir anseios restauradores. O movimento, no qual estava envolvido José Bonifacio, pretendia derrubar o ministério ou a Regência e, quiçá, reivindicar a volta de Pedro I. Jornais, panfletos, manifestos e processos judiciais constituem as principais fontes de pesquisa.

Palavras-chave: Período Regencial. Rio de Janeiro. Revolta de 17 de abril de 1832.
\end{abstract}

Fase mais agitada e conturbada da história do Brasil e também uma das mais ricas e singulares em termos de organização, discussão e participação políticas, o Período Regencial (1831-1840) é, contudo, ainda muito pouco explorado pela historiografia. Tanto assim, que

* Marcello Basile é Doutor em História Social pela UFRJ e professor-palestrante do curso de pós-graduação lato sensu História do Brasil: economia, sociedade, política e cultura, da Universidade Candido Mendes.

Anos 90, Porto Alegre, v. 11, n. 19/20, p.259-298, jan./dez. 2004 
a maior referência sobre o assunto continua sendo o conjunto de biografias dos fundadores do Império, produzidas por Octavio Tarquinio de Sousa (1957) entre as décadas de 1930 e 1950. Muito se deve ainda às obras pioneiras de Moreira de Azevedo, datadas do século XIX (Moreira Azevedo, 1871, 1873, 1874a, 1874b, 1875, $1876,1884,1885)$. O único tema a merecer maior número de estudos - assim mesmo, em sua maioria, factuais e apologéticos - é o das grandes revoltas provinciais, Farroupilha, Cabanagem, Balaiada, Sabinada e Guerra dos Cabanos, ${ }^{1}$ Mas permanecem pouco conhecidos diversos outros movimentos semelhantes que, não obstante suas menores dimensões, foram bem mais numerosos e disseminados pelo Império, causando, no conjunto, impacto quase tão profundo quanto o das grandes revoltas. ${ }^{2}$

Este artigo analisa uma das principais revoltas então ocorridas no Rio de Janeiro: a que, capitaneada pelos caramurus, sacudiu a capital do Império em 17 de abril de 1832. A aguda crise política produzida inicialmente pela oposição a Pedro I e, em seguida, na disputa pelo governo regencial, em consonância com a vagatura do Trono e a falta de unidade, até então, da elite política imperial, ensejaram a formação de três facções distintas - as dos chamados liberais moderados, liberais exaltados e caramurus -, portadores de diferentes projetos políticos.

Situados ao centro do campo político imperial, os moderados apresentavam-se como seguidores dos postulados clássicos liberais, tendo em Locke, Montesquieu, Guizot e Benjamin Constant suas principais referências doutrinárias. Pretendiam - e nisso foram bem sucedidos - realizar reformas político-institucionais que reduzissem os poderes do imperador, conferissem mais prerrogativas à Câmara dos Deputados e autonomia ao Judiciário e garantissem a observância dos direitos (civis, sobretudo) de cidadania previstos na Constituição, instaurando uma liberdade moderna que não ameaçasse a ordem imperial. Já à esquerda do campo, adeptos de um liberalismo radical de feições jacobinistas, estavam os exaltados, que, inspirados principalmente em Rousseau, buscavam conjugar princípios liberais clássicos com ideais democráticos. Pleiteavam profundas reformas

Anos 90, Porto Alegre, v. 11, n. 19/20, p.259-298, jan./dez. 2004 
políticas e sociais, como a instauração de uma república federativa, a extensão da cidadania política e civil a todos os segmentos livres da sociedade, o fim gradual da escravidão, uma relativa igualdade social e até uma espécie de reforma agrária. Os caramurus, por sua vez, ficavam à direita do campo, alinhando-se à vertente conservadora do liberalismo, tributária de Burke. Críticos ferrenhos da Abdicação e avessos a qualquer reforma na Constituição de 1824 - ações tidas como uma quebra arbitrária do pacto social -, defendiam uma monarquia constitucional fortemente centralizada, nos moldes do Primeiro Reinado, chegando, em casos excepcionais, a nutrir anseios restauradores. Tais projetos revelam concepções e propostas distintas acerca da nação que, cada qual à sua maneira, pretendiam construir e inserem-se em uma cultura política multifacetada ou híbrida, que combinava as idéias liberais mais avançadas com resíduos absolutistas do Antigo Regime. ${ }^{3}$

Com a pronta ocupação do governo regencial pelos moderados - que se achavam mais bem organizados politicamente - e o conseqüente alijamento dos exaltados (que, com eles, protagonizaram o 7 de Abril) e dos caramurus (identificados aos antigos adeptos de Pedro I) -, a disputa política extrapolou o embate de idéias e transbordou para as ruas, transformando-se em luta aberta e violenta pelo poder. Tal como as províncias, a Corte foi palco então de uma série de movimentos de protesto e revolta. Primeiro foram os exaltados, com quatro malogradas ações desse tipo entre julho de 1831 e abril de 1832, e, em seguida, foi a vez dos caramurus.

\section{Viva Dom Pedro I: a aventura do barão de Bulow}

Tão logo debelada a última sedição exaltada de 3 e 4 de abril, surgiram novos rumores dando conta de que outra revolta estaria prestes a eclodir, desta vez sob os auspícios dos caramurus. Suspeitavase do envolvimento do próprio tutor de Pedro II na trama restauradora, o que parecia confirmado pela insistência de José Bonifacio em manter seu pupilo isolado na Quinta da Boa Vista. ${ }^{4}$ O clima tenso favorecia ainda mais a proliferação dos rumores. 
Revoltas regenciais na Corte: o movimento de abril de 1832

No dia 8, correu o boato de que "dois mil e tantos rusguentos" achavam-se reunidos nas localidades de Campinho e Irajá, a caminho da cidade. As guardas Nacional e Municipal Permanente foram acionadas, mas verificaram que tudo "não passou de um fantasma" e que a população local estava também sobressaltada com o boato contrário de que "um exército de 6.000 homens vindos da cidade, pretendia talar-lhes os campos, e incendiar suas míseras choupanas". ${ }^{5}$

Os rumores, porém, não eram de todo sem razão. Segundo a versão oficial, narrada em comum pelo governo e por seus portavozes informais, os jornais moderados, ${ }^{6}$ na tarde do dia 16, dois caramurus - de acordo com a Aurora Fluminense, "dois Negociantes, abalados em seu crédito comercial, e conhecidos como instrumentos da facção restauradora" " - foram ao Arsenal de Marinha e tentaram seduحir a guarda, dizendo que entregasse o Arsenal a um grupo de homens de bem que desembarcaria ali após a meia noite. A guarda, todavia, imediatamente comunicou o ocorrido ao comandante superior da Guarda Nacional, que logo preveniu os comandantes dos corpos e tomou as providências necessárias para prender os dois homens (um foi pego ainda naquela noite, e o outro, no dia seguinte) e assim surpreender o grupo de assalto.

Já passava da meia noite quando o capitão-tenente da Marinha Joaquim Leão da Silva Machado, o capitão do Exército Luiz Henriques Tota e os tenentes-coronéis Conrado Jacob de Niemeyer e Marcos Antonio Bricio ${ }^{8}$ embarcaram em uma falua, no cais da Glória, em direção à fragata Imperatriz. Abordando essa embarcação, Machado apresentou ao comandante da Imperatriz uma requisição, em que constava a assinatura do chefe-de-divisão João Taylor, para que lhe fossem entregues cinqüenta marinheiros armados. Estes embarcaram assim, com mais dois oficiais da fragata, em uma lancha, rumando, junto à falua, para a praia da Glória, de onde marchariam até o Arsenal de Guerra para tomá-lo de surpresa. Contudo, suspeitando de que algo estivesse errado, o comandante da fragataprontamente comunicou o fato ao governo.

Às duas horas da manhã, o rebate das matracas ecoou pelas ruas da Corte, mobilizando prontamente as guardas Nacional e

Anos 90, Porto Alegre, v. 11, n. 19/20, p.259-298, jan./dez. 2004 
Municipal Permanente e o batalhão voluntário de Oficiais-Soldados, que foram distribuídos por diversos pontos da cidade. Assim, ao tentar desembarcar na Glória, o grupo foi repelido à bala pela Guarda Nacional da freguesia de São José. Os marinheiros e oficiais da fragata, percebendo que não estavam sob as ordens do governo (ou, talvez, se dando conta de que o plano não dera certo), bateram em retirada pelo mar, mas foram logo alcançados por uma barca, proveniente do Arsenal de Marinha. Esta, em seguida, interceptou também os tripulantes da falua, quando tentavam fugir em direção à Villa Real da Praia Grande (Niterói); os quatro homens foram presos e enviados à fortaleza da Lage.

Enquanto isso ocorria, porém, outro grupo muito maior de revoltosos reunia-se no outro lado da cidade, próximo à Quinta da Boa Vista. Os relatos apontam uma força de cerca de duzentos e cinqüenta a quatrocentos homens, ${ }^{9}$ em sua maioria composta por criados do Paço imperial, guardas nacionais das freguesias do Engenho Velho, São Cristóvão e Benfica, oficiais brasileiros e alguns estrangeiros, além de uma chusma de vadios e africanos. No comando, estaria o barão de Bulow, ${ }^{10}$ coadjuvado pelo coronel Antonio Joaquim da Costa Gavião. Segundo Moreira de Azevedo (1875, p.134), os revoltosos usavam como distintivo "um laço vermelho no peito, como os companheiros de Camillo Desmoulins na revolução francesa". O redator d'O Carijó fez então um breve discurso a seus companheiros, que terminou com vivas a Dom Pedro I. Em seguida, o grupo partiu em direção ao Campo da Honra (atual Campo de Santana), tradicional ponto de manifestações públicas populares da cidade, levando consigo duas peças de artilharia. ${ }^{11}$ Chegou então ao Largo do Rossio Pequeno (Praça Onze de Junho), repetindo os vivas a Pedro I, agora estendidos aos irmãos Andrada. Ali os manifestantes foram informados por um destacamento, enviado à frente para verificar a situação no centro da cidade, que a Guarda Nacional já se achava no Campo da Honra, pronta a atacá-los. Resolveram assim bater em retirada, mas, na altura do Barro Vermelho, foram cercados pelos batalhões de Cavalaria e da freguesia do Sacramento da Guarda Nacional (comandados, respectivamente, pelo tenente-coronel José 
Revoltas regenciais na Corte: o movimento de abril de 1832

Dias da Cruz Lima e pelo então major Luís Alves de Lima e Silva ${ }^{12}$ ), pela Guarda Municipal Permanente (a cargo do tenente-coronel Francisco Theobaldo Sanches Brandão) e pelo esquadrão de Minas (sob as ordens do capitão Antonio Joaquim Mascarenhas Peçanha), que abriram fogo sobre os revoltosos. Estes não resistiram a mais do que cerca de quinze minutos de tiroteio, sendo fragorosamente derrotados. A maior parte fugiu, escondendo-se nas chácaras e casas da vizinhança, alguns foram presos e vários ficaram feridos. Os números do combate, sempre imprecisos, apontam de dez a vinte manifestantes mortos. ${ }^{13}$ Da parte das forças do governo, apenas um guarda municipal permanente e o capitão Peçanha morreram, ${ }^{14} \mathrm{e}$ dois outros sofreram ferimentos: o tenente-coronel Theobaldo e o anspeçada (depois promovido a furriel, pelo auxílio prestado a Peçanha durante a luta) Luiz Antonio de Azevedo.

Clamando desde o Levante da Ilha das Cobras pela adoção de medidas enérgicas de exceção para combater a anarquia, não estava o governo disposto a dar trégua aos participantes da intentona caramuru. Assim, iniciou uma caçada aos indivíduos identificados que escaparam de ser presos durante o combate, a começar pelos militares. É esse o sentido da ordem expedida pelo comandante das Armas da Corte:

Tendo desaparecido os Srs. Coronel Antonio Joaquim da Costa Gavião, Capitão Antonio Pinto Homem, João Maria de Sampaio, André Pinto Duarte da Costa Pereira, Tenentes Antonio de Saldanha da Gama, José Pinto Duarte da Costa Pereira, e Segundo Tenente João Manoel Martins Filgueiras, desde o dia 17 do corrente, determino não só aos Srs. Comandantes das Classes que os façam prender, como também aos Srs. Oficiais que os encontrarem. ${ }^{15}$

Mesmo os militares e milicianos que não atenderam então ao toque das matracas ficaram sob suspeita de, no mínimo, cumplicidade ou conivência com os revoltosos e foram também alvos de investigação. Já a ordem do dia 17 intimava rispidamente todos

Anos 90, Porto Alegre, v. 11, n. 19/20, p.259-298, jan./dez. 2004 
os comandantes de classes do Exército que compareceram e que não se apresentaram à convocação daquela madrugada que dessem

[...] imediatamente conta aqueles dos que faltaram, e estes dos motivos para não comparecerem em uma ocasião em que não se deviam negar ao serviço da Nação que lhes paga, visto que o seu patriotismo os não moveu a cumprirem seus deveres. ${ }^{16}$

Da mesma forma, em ordem do dia 18, o comandante do batalhão da Guarda Nacional de São José determinou a todos os comandantes de companhia que "me remeterão sem demora as Relações das faltas com notas dos indivíduos que tiverem reincidido nelas nesta ocasião de defenderem a Pátria ameaçada pelos perturbadores da prosperidade dela". ${ }^{17}$ As mesmas suspeitas foram lançadas pelos jornais moderados, por vezes gerando reações. ${ }^{18}$

A busca rendeu frutos, pois vários militares foram presos por participação na revolta. Embora não se tenha conhecimento de todos, foram identificados os tenentes-coronéis Conrado Jacob de Niemeyer e Marcos Antonio Bricio, os capitães Luiz Henriques Tota, Antonio Pinto Homem e João Maria da Silveira Sampaio, o segundo-tenente João Manoel Martins Filgueiras, o chefe-de-divisão João Taylor e o capitão-tenente da Marinha Joaquim Leão da Silva Machado, todos enviados à Fortaleza da Lage e daí para a de Santa Cruz. Destes, sabe-se que ao menos Bricio, Tota, Niemeyer, Machado e Taylor foram levados ao Conselho de Guerra, que absolveu os dois primeiros e condenou os três últimos em primeira instância; mas, depois, foram todos absolvidos pelo Conselho Supremo Militar de Justiça. ${ }^{19}$ Os demais devem ter sido inocentados; se não, foram contemplados com a lei de Anistia aos presos políticos, de 8 de outubro de 1833.

O mesmo não aconteceu, porém, com o barão de Bulow, indigitado como chefe da revolta. Durante o combate, Bulow conseguiu escapar, refugiando-se na Quinta do Macaco (no atual bairro de Vila Isabel), de propriedade do americano Maxwell. Informada de que o fugitivo achava-se ali, a polícia realizou, em 24

Anos 90, Porto Alegre, v. 11, n. 19/20, p.259-298, jan./dez. 2004 
de abril, uma batida no local, encontrando-o escondido em um caixão dentro de um alçapão subterrâneo cheio de café situado sob o quarto do feitor da chácara. ${ }^{20}$ Preso, foi condenado a 9 de novembro de 1833 pelo júri a dez anos de prisão com trabalhos, ${ }^{21}$ sentença confirmada depois pelo Tribunal da Relação. Contudo, o decreto regencial de 7 de maio seguinte comutou a pena para banimento do Império. No mesmo dia em que Bulow foi preso, a polícia também efetuou busca na Quinta da Boa Vista e lá apreendeu considerável quantidade de objetos de armamento e munição, localizados em vários quartos. ${ }^{22} \mathrm{O}$ achado aumentou ainda mais as suspeitas de envolvimento do tutor na conspiração, dando força ao movimento que pretendia derrubar o Andrada enquanto cabeça da facção caramuru. ${ }^{23}$

Se os periódicos moderados deram ampla cobertura ao movimento, conferindo-lhe um caráter restaurador, as folhas caramurus mostraram-se hesitantes ou mesmo controversas em comentá-lo. Dos jornais pesquisados, o primeiro a noticiá-lo, mais de um mês depois, foi o Caramuru, que, tal como acerca do levante de 3 e 4 de abril, condenou a ação, vista como uma "impolítica tentativa com que, por um meio arriscado, se buscava conseguir a restauração. Embora responsabilizando a tirania do governo pela atitude extremada, o jornal reprovava esses meios, relatando que "meia dúzia de loucos desesperados pelo jugo de ferro de uma Administração Sanguissedenta buscou desoprimir-se dela por um meio revolucionário, e criminoso em prol da restauração". ${ }^{24} \mathrm{O}$ redator procurava, assim, defender-se mais uma vez da imputação de participante do movimento, o que vinha the valendo uma série de perseguições.

Já $O$ Carijó e $A$ Trombeta limitaram-se a publicar, em junho, respectivamente um artigo e um manifesto, assinados por Bulow. Neste último, escrito da Fortaleza da Lage a 26 de maio, o barão justificou a revolta com base no liberal princípio do direito de resistência à tirania e opressão: "Se eu quisesse fundar a legalidade dos acontecimentos de 17 de Abril sobre estas bases, não me seria necessário para a justificar mais que citar as arbitrariedades e

Anos 90, Porto Alegre, v. 11, n. 19/20, p.259-298, jan./dez. 2004 
violências cometidas pelo Governo". Pretendia também "mostrar, e provar que o Governo foi sabedor com muita antecedência dos sucessos de 3 d'Abril, e promotor dos de 17, e por conseqüência culpado das mortes". Para isso, recordava sua antiga amizade com Feijó, com quem rompera ao perceber "O manejo obscuro, e triste do dito Ministro, e o descaramento com que o Governo semeava o ódio entre os pacíficos habitantes", pondo-se então a escrever $O$ Carijó "para fazer ver ao povo a má fé dos que o governavam". Perseguido, refugiou-se na casa do coronel Gavião, onde conheceu certo C. de M., doutor em Medicina pela Universidade de Bolonha, que apresentava planos de revolta, mas que seria, na verdade, agente infiltrado do governo.

Os avisos passados à Guarda Nacional e a movimentação prévia das tropas de linha e dos permanentes seriam provas de que o governo sabia da ação e a promovera para justificar a repressão aos oponentes. Longe de negar sua participação no movimento, Bulow dizia que "me achava no dia 17 reunido aos defensores da liberdade" e que, ancorado no direito de resistência, "julguei a nossa reunião em S. Cristóvão uma operação Nacional". Esta nada teria de criminosa:

Diz a Constituição que todo o Cidadão pode fazer o que a lei não proíbe; ora qual é a Lei que proíbe dar vivas ao Sr. D. Pedro $1^{\circ}$, a um Príncipe que foi fundador do Império, e que deu ao Brasil Independência, e Liberdade? Estou persuadido que nenhuma lei há, pela qual possamos ser qualificados de criminosos por este fato, nem ainda mesmo que tivéssemos proclamado a restauração desse desditoso Príncipe, por isso que sem um prévio julgamento Nacional foi forçado a abdicar uma Coroa, que o Pacto Social do Império lhe garantia para sempre e que sendo inviolável, e sem responsabilidade não podia cometer crimes. ${ }^{25}$

Seguindo a mesma linha de raciocínio baseada nos princípios liberais do direito de resistência, do pacto social e do

Anos 90, Porto Alegre, v. 11, n. 19/20, p.259-298, jan./dez. 2004 
constitucionalismo, o artigo publicado n'O Carijó rebatia as críticas feitas pelo Caramuru ao movimento, sustentando que "todo o homem que toma as armas, em defesa das Leis, e da Liberdade, nunca pode ser classificado criminoso" e que seu intento era apenas "defender a Constituição Jurada, não querendo outra coisa que a deposição do Ministério, usando dos mesmos meios e passos como os do dia 7 de Abrill". Neste sentido, somente cumprira seu dever, sendo então a ação "legal, e Nacional". ${ }^{26}$

Ao se ouvirem outras vozes, portanto, novos significados vão revestindo o movimento de feições distintas daquela de um ato meramente sedicioso e restaurador. As investigações feitas para apurar os fatos apontam melhores indícios sobre esses outros matizes. Poucas horas após os "tristes e criminosos acontecimentos", na tarde do mesmo 17 de abril, o superintendente da Quinta da Boa Vista, Faustino Maria de Lima e Fonseca Gutierres, procedeu a uma sindicância no local, interrogando as "pessoas que ali achei". Sete testemunhas foram ouvidas, mas quase nada informaram. A primeira delas, o frei João Nepomuceno, disse simplesmente que "nada sabe". A segunda, o bibliotecário G. Lasserra, relatou apenas que "ouvira muita bulha e chando [sic] à janela, e vendo muita gente não conheceu senão algumas pessoas da casa". A terceira, o escriturário Antonio Egidio de Miranda, declarou "não saber do Administrador Miguel Gonçalves e que desde ontem à noite não comparece em Casa". A quarta, o fiel da Administração Joaquim dos Reis, limitouse a dizer que "estivera no largo do Paço onde via muita gente e que retirando-se para sua Casa não acsistira [sic] ao menor barulho". A quinta, o feitor de capim Joaquim Leite de Azevedo, respondeu que "às horas do costume passara revista a toda a Escravatura e que não lhe faltando ninguém recolheu-se ao seu quarto sem que de nada soubesse". A sexta, o caixeiro imperial Joze Rodrigues, analfabeto, declarou que "viera ao Largo do Paço, diz que vira gente da Imperial Casa e de fora e que tendo marchado aquela gente com as duas Peças ele se recolhera para sua Casa e que desde então lhe faltam Supriano Villa Nova Caixeiro dos Senhores e Roque Luiz Fiel da Cocheira". A sétima testemunha, por fim, o fiel das Imperiais 
Cavalariças Manoel Joaquim, relatou que "quando vieram os moços das Cavalariças para o Largo veio também com eles e vendo muita gente pronta para marchar com as duas Peças acompanhou-os até o Portão e depois voltara para Casa e que desde então lhe faltam o Fiel das Cavalariças Joze Joaquim Pinto e os Moços das mesmas Cavalariças João de Almeida e Joze Vaz, e que igualmente falta o Corrieiro, e save [sic] por ouvir dizer que o Sacrista [sic] Jozé Maria morrera no Hospital". ${ }^{27}$

É evidente a intenção das testemunhas - pessoas que trabalhavam e moravam no local e que decerto sabiam mais do que falaram - de não se comprometerem. Mas já o terceiro, sexto e sétimo depoimentos apontam o envolvimento de empregados do Paço no movimento, indivíduos que foram mortos ou feridos no combate ou que, como é mais provável, resolveram desaparecer por algum tempo para evitar a prisão. É possível que não tenha passado disso a sindicância interna, mas outra investigação, esta judicial, iria apurar melhor os acontecimentos.

Ainda no dia 17, o juiz de paz da freguesia de São José, João Silveira do Pillar (sócio da moderada Sociedade Defensora), instaurou um sumário (formação de culpa) para investigar a "conspiração com força armada para derrubar o Governo existente", ocorrida na madrugada daquele dia. ${ }^{28}$ Foram convocadas para depor dez testemunhas, que estavam presas no quartel da Guarda Municipal Permanente "por serem apanhadas com armas na mão na sedição". 29

As três primeiras e a nona testemunhas na fila do escrivão estavam envolvidas com o grupo da Glória que tentaria tomar de assalto o Arsenal de Guerra. Percebe-se então que aquele bando era bem maior e mais diversificado socialmente do que apontam os relatos oficiais. A primeira testemunha, Manoel José da Costa, vinte e um anos de idade, português natural da Vila do Conde, caixeiro da loja de José Bento Ferreira (na Rua Direita, hoje Primeiro de Março), declarou que Dom Antonio de Saldanha pedira-lhe que levasse para ele duas pistolas carregadas até o Arsenal do Exército, devendo antes encontrar Antonio Lopes Crises e juntos embarcarem na praia da Glória rumo ao Arsenal. No caminho, porém, ambos

Anos 90, Porto Alegre, v. 11, n. 19/20, p.259-298, jan./dez. 2004 
foram presos por uma patrulha da Guarda Nacional ao pé do Pocinho da Glória. ${ }^{30}$ A segunda testemunha foi Antonio Lopes Crises, trinta e quatro anos, português, caixeiro de Saldanha - o mesmo que agenciou Manoel da Costa e que, segundo Crises, também lhe pediu que, armado, encontrasse com Costa e com Antonio Ribeiro de Paiva no portão de sua chácara para que daí se dirigissem para o Largo de Nossa Senhora da Glória, onde iriam embarcar rumo ao Arsenal. ${ }^{31} \mathrm{O}$ último do trio, Antonio Ribeiro de Paiva, de apenas dezesseis anos de idade, também caixeiro, foi a testemunha seguinte, a qual confirmou toda a história, declarando ter sido mandado por seu patrão, José Bento Ferreira (o mesmo de Manoel da Costa), para encontrar-se com Crises e Costa, de quem recebeu no caminho para o embarque uma das duas pistolas que levava; os três acabaram presos no local indicado. ${ }^{32}$ A outra testemunha envolvida no caso, Thomé Luiz dos Santos, provavelmente escravo, de idade desconhecida, contou que, por volta das dez horas da noite, tendo ido de sege com seu senhor, Joaquim Ferreira Batalha, à casa do já conhecido Saldanha, na rua da Pedreira da Glória (atual Pedro Américo), após os dois conversarem, seu senhor saiu e mandou que aguardasse ali até que Saldanha o solicitasse; às onze horas, este lhe deu um bilhete para levar até Batalha, que foi entregue. Mas a história termina aí, pois o restante do depoimento acha-se ilegível..$^{33}$

De todo modo, fica clara a intenção das testemunhas de não se comprometerem, dando impressão de que nada sabiam do movimento e de que estavam no local apenas cumprindo ordens. Difícil é crer, no caso dos três caixeiros, que fossem armados, em grupo e de madrugada ao Arsenal de Guerra, vindo de um lugar ermo como a praia da Glória, sem que ao menos soubessem o que se passava. Mais provável é que estivessem de acordo com seus patrões e fossem os três (e quem sabe outros) juntar-se ao grupo oriundo da fragata Imperatriz, que iria ali desembarcar, para depois seguirem até o Arsenal. Vale realçar a participação de negociantes possivelmente também portugueses - no papel de agenciadores, como Dom Antonio de Saldanha. Quanto ao escravo, o ponto até 
onde se pôde acompanhar sua história não permite fazerem-se maiores ilações.

As demais testemunhas estavam envolvidas na ofensiva do Engenho Velho. A primeira - quarta da lista - era Manoel José de Araújo (dados pessoais ilegíveis), que declarou ter visto o capitão fuão Carvalho, o tenente fuão Rocha e o alferes fuão Salles, todos da $6^{a}$ Companhia de Infantaria, convocando os guardas nacionais em suas casas para se reunirem, e, entre duas e três horas da manhã, viu quando o capitão da $2^{\text {a }}$ Companhia de Cavalaria, José Coelho da Silva, e alguns soldados encontraram-se na cancela de São Cristóvão com quatro oficiais (um destes era o capitão reformado fuão Sampaio), os quais disseram ao capitão que aprontasse logo o pessoal para marchar até a cidade. Reunida a tropa, viu um "Oficial que falava Espanhol" (decerto Bulow) puxar vivas a Dom Pedro I e colocar o grupo em marcha até o Rossio da Cidade Nova, de onde tivera que retroceder para evitar o confronto com as forças do governo. Porém, ao se deparar no Curtume com a Guarda Municipal Permanente, o tiroteio tornou-se inevitável. ${ }^{34}$ A quinta testemunha, Manoel da Silva, trinta e três anos, natural do Porto, criado de servir de Antonio José Duarte e morador da Cancela de São Cristóvão, afirmou que saíra pela manhã para comprar milho e aproveitara para observar os mortos no combate, quando foi preso, "talvez por trazer ele respondente um colete com botões de Pedro primeiro". 35 Já o sexto depoente, Joaquim Antonio (dados pessoais ilegíveis), disse que ele e seus companheiros reuniram-se à Guarda Nacional de Infantaria do Engenho Velho e, notando chegar após a meia noite vários oficiais, "entre os quais havia dois que falavam Estrangeiro dos quais um que falava Espanhol que se lhe disse ser o barão de Bulow tomou conta do Comando da força, e deu vivas a Pedro Primeiro que foi respondido com grande entusiasmo”. Em seguida, Bulow teria concitado a tropa a marchar para o Campo da Honra, afirmando que as guardas Nacional e Permanente e o batalhão de Oficiais-Soldados já teriam aclamado o ex-Imperador. O depoente disse ainda que fora preso pelos permanentes no combate com as forças do governo quando fugia em direção à Quinta. ${ }^{36}$ A Sétima

Anos 90, Porto Alegre, v. 11, n. 19/20, p.259-298, jan./dez. 2004 
testemunha, João Manoel de Azevedo, quarenta e dois anos, natural de Barcellos, administrador do curtume onde estacionou a força rebelde, também notara, no ajuntamento, oficiais de diferentes corpos, um dos quais dava ordens em espanhol e disseram-lhe ser o barão de Bulow, bem como o capitão reformado João Maria de Sampaio. Afirmou ter então desconfiado que "houvesse traição naquela força, e cuidou logo em retirar-se, porém nessa ocasião, foi repelido" e preso pelos permanentes, que acharam em seu quarto a farda e o boné molhados, daí inferindo sua participação no levante. Perguntando o juiz se reconhecera mais alguém, respondeu que vira alguns oficiais da Artilharia Montada, entre os quais o cadete, filho de um boticário, Antonio Soares Fonseca. ${ }^{37} \mathrm{~A}$ oitava testemunha, Antonio da Cruz de Almeida (dados pessoais ilegíveis), afirmou que entrara no ajuntamento porque seu patrão, o capitão João Henrique Junho Laquemar, ordenara que se reunisse, com espingarda e patrona, aos criados da Quinta, onde também notou muitos oficiais, inclusive um que falava espanhol e disseram-lhe ser Bulow. Este é quem teria dado a ordem de marchar para a cidade e de fazer fogo sobre os permanentes, nas proximidades do Curtume, "sendo os mesmos Oficiais os primeiros que sobre ela dispararam". Durante o combate, o depoente fugira, escondendo-se em uma chácara, onde fora preso. ${ }^{38}$ Por fim, a décima testemunha, José Marques da Silva, quarenta e seis anos, português, dono de uma serralheria no Pedregulho (Benfica), disse que, sendo guarda nacional da $6^{a}$ Companhia de Infantaria do Engenho Velho, atendeu a chamado de seus colegas, juntando-se a eles na cancela de São Cristóvão, sob o comando do capitão dessa companhia Antonio de Carvalho e do tenente fuão Rocha. Estes os conduziram até o largo do Paço da Boa Vista, cujos criados já estavam lá reunidos, fardados e armados, juntamente com o delegado da Quinta, Miguel de tal. Entre uma e duas horas da manhã, na altura da ponte de Manoel Caetano Pinto (em São Cristóvão), parte da Cavalaria de Benfica, liderada pelo capitão José de tal Coelho, reuniu-se àquela força. Logo depois, chegaram indivíduos a cavalo, informando que Pedro I fora aclamado no campo de Santana, em decorrência do que repetidos vivas foram dados ao 
ex-imperador. Em seguida, narrou a seqüência da marcha até a Cidade Nova e do combate no Curtume, repetindo que a ordem para atirar partira dos oficiais rebeldes. Disse, enfim, que fugira com outros logo no início do tiroteio, sendo preso na estrada. ${ }^{39}$

No dia 25, mais duas testemunhas foram convocadas para corpo de delito (inquérito policial): José Maria Hespanha, vinte anos, solteiro, natural do Rio Grande do Sul, e Francisco Antonio de Macedo, dezoito anos, natural de São Paulo, ambos guardas municipais permanentes. Os dois nada acrescentaram aos depoimentos anteriores, declarando igualmente terem visto o "ajuntamento ilícito", composto por guardas nacionais de Infantaria e Cavalaria e por criados do Paço armados e com duas peças de artilharia, os quais, na altura da chácara do Curtume, entraram em combate com o batalhão de que eles, testemunhas, faziam parte. ${ }^{40}$

Ainda no dia 25, o juiz de paz de São José pronunciou a prisão e livramento de Manoel José de Araújo, Antonio da Cruz de Almeida e dois fuãos (as testemunhas Manoel José da Costa e Joaquim Antonio). ${ }^{41}$ Surpreende, contudo, o pequeno número de pronunciados, já que vários outros aparecem implicados nos autos, entre eles o barão de Bulow, apontado por várias testemunhas como principal liderança do movimento e nem assim pronunciado. Dessa forma, no mesmo 25 de abril, outro sumário foi aberto para apurar a "conspiração", agora por Agostinho Moreira Guerra, juiz do crime do bairro da Candelária. O sumário tinha justamente Bulow como réu, bem como o coronel Gavião e Miguel Gonçalves dos Santos, delegado do juiz de paz do Engenho Velho e administrador da Quinta. ${ }^{42}$ Como estes dois últimos estavam foragidos, apenas o barão (preso na Casa da Suplicação) foi então submetido a interrogatório.

Indagado sobre onde estivera na madrugada do dia 17, Bulow respondeu que, na noite anterior, fora à casa de Gavião, a convite deste, de Miguel dos Santos, de certo Saldanha, ${ }^{43}$ de outro coronel e de quatro oficiais subalternos cujos nomes ignorava, que o convidaram para reunir-se em São Cristóvão, alegando que "toda a Cidade estava de acordo para pedir a demissão do Ministério". Bulow revelou então suas motivações pessoais para participar da empreitada: 
"e como ele Respondente fora ofendido gravemente com injustiça, pelo Excelentíssimo Ministro da Justiça por quem havia exposto a sua vida até o ponto de lhe dar Ordens para conduzir a Tropa de São Cristóvão para a Cidade na ocasião da revolta da Ilha das Cobras, não duvidou anuir ao convite pois que via aí pessoas de representação". Revelou também a existência de um suposto plano para assassinar o Presidente da Regência, relatando a chegada à casa de três homens vestidos como guardas municipais, os quais disseram que Lima e Silva acabara de ir para sua chácara e que esta seria a melhor oportunidade para matá-lo, ao que "ele Respondente obstou a semelhante pretensão pois já havia vinte homens de emboscada no Pedregulho para serem executores do Assassínio". Pouco depois, por volta de duas horas, chegaram dois oficiais e vários municipais dizendo que deviam partir, e então todos seguiram para a Boa Vista, onde já se encontravam as duas peças de artilharia e cerca de oitenta pessoas de Infantaria e Cavalaria, armadas. Mas, vendo a multidão em desordem - uns queriam marchar, outros não, "alguns diziam em gritos viva Dom Pedro Primeiro, e outros viva Dom Pedro Segundo" -, reclamou com Gavião que este "o havia comprometido pois que contava que todo o Povo estivesse pronto e que assim se via enganado". O coronel retrucou que, no campo da Honra, havia mais gente para se reunir a eles. Decidiu então conduzir a multidão até lá, mas, nada encontrando no Rossio Pequeno e ouvindo do próprio Gavião que também naquele campo não havia ninguém, resolveu regressar. Contrariando as testemunhas, Bulow assegurou que, achando que estivesse comprometido e sua retaguarda fechada, abandonou a tropa no caminho de volta e fugiu a cavalo, ocultandose na chácara onde depois foi preso, sem que o dono desta soubesse. Instado pelo juiz a dizer a verdade, pois constava que partira do réu a ordem para atacar os permanentes, reiterou Bulow que havia se retirado antes do início do combate e que, portanto, era falsa aquela informação. Em seguida, foi-lhe perguntado se fizera algum discurso à multidão, ao que respondeu, mais uma vez contrariando as testemunhas, que "só disse que se aquela era a vontade do Povo Brasileiro como se lhe assegurava, que estava pronto a 
acompanhá-los pois conhecia a vontade do Povo por Soberana". Negou aindaque soubesse previamente de alguma combinação sediciosa e que estivesse escondido na Quinta antes do dia 16, mas reconheceu que

fora algumas vezes ali jantar com os Andrada, até que estes, sabendo que era perseguido pela Justiça, ${ }^{44}$ pediram que não mais voltasse para não comprometer a Casa. Por fim, de novo expondo suas ligações pretéritas com os revoltosos, disse que, durante aquele tempo, refugiou-se em algumas casas e até a bordo de um barco estrangeiro, com o apoio da "gente do Taylor". 45

No dia seguinte (26), entre os objetos apreendidos na residência do barão, estavam um jogo de pistolas carregadas e várias fardas do Exército brasileiro. A pedido de Bulow, dois peritos foram chamados para verificar o estado do fardamento, sob alegação de que o traje nunca fora usado, "exceto quando os permanentes depois que o prenderam o obrigaram a isso". De fato, o exame constatou que as fardas ainda não tinham sido usadas. ${ }^{46}$

No dia 27, duas testemunhas foram convocadas para o corpo de delito indireto. Uma era Joaquim dos Reis Pernis, português do Alentejo, cinqüenta anos, casado, morador e fiel dos armazéns da Quinta da Boa Vista, que contou ter sido chamado pelo administrador para ir armado até o pátio do Palácio e, lá chegando, achou muitos guardas nacionais e criados do Paço reunidos. Ouviu, então, falar no barão de Bulow, e de lá partiram para a cidade, "querendo ele testemunha escapar-se e o não pôde conseguir senão adiante da ponte de Manoel Caetano Pinto, e Retirou-se para sua Casa", apenas escutando depois os tiros. ${ }^{47}$ A segunda testemunha, José de Lemos, também português (de Lisboa), trinta e um anos, solteiro, morador da Quinta, empregado como correio da Regência, declarou que dois homens o chamaram em sua casa para comparecer armado ao pátio do Palácio e, aí chegando, foi logo preso, juntamente com o colega Antonio José, "por serem Correios e não virem para a Cidade dar parte". Notou, todavia, muita gente de Cavalaria e Infantaria reunida, esta comandada por Bulow e aquela pelo coronel Gavião. Quando marchavam para a cidade, conseguiu escapar, retornando à Quinta. ${ }^{48}$

Anos 90, Porto Alegre, v. 11, n. 19/20, p.259-298, jan./dez. 2004 
Revoltas regenciais na Corte: o movimento de abril de 1832

No mesmo dia, além dessas duas testemunhas (agora a terceira e a quarta ouvidas, que reproduziram integralmente seus depoimentos), ${ }^{49}$ outras quatro foram inquiridas no sumário. A primeira, João Vicente, português, com mais de trinta anos, solteiro, morador da Boa Vista, onde era moço das ordens do imperador e das princesas, também disse que, às onze horas da noite do dia 16, fora chamado em casa para pegar em armas, pelo cocheiro Antonio Joaquim, a mando do delegado Gonçalves. Dirigiu-se então à casa deste, onde se armou e viu muita gente armada, seguindo todos para o pátio do Palácio. Logo chegaram vários oficiais, dos quais só conhecia Bulow e Gavião. Durante a marcha até a cidade, conseguiu voltar para casa, sabendo depois que "o Delegado andou seduzindo as Pessoas empregadas na Quinta". ${ }^{50}$ A segunda testemunha, Alexandre Fortuna, trinta e seis anos, casado, igualmente português e morador da Quinta,

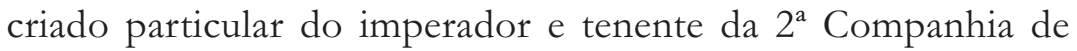
Cavalaria da Guarda Nacional do Engenho Velho, disse que estava doente em casa e que só ouviu os tiros do combate, sendo depois informado de que fora a "gente de São Cristóvão" que marchara para a cidade e fora batida no caminho, e que, à testa dos revoltosos, estavam Bulow e vários oficiais. ${ }^{51} \mathrm{O}$ quinto depoente era outro português, José Maria Brioto, quarenta e um anos, casado, morador do Engenho Velho, criado de Samuel Felype, que afirmou ter saído a cavalo de casa, às três horas da madrugada, armado de espada, por ter ouvido o rebate das cornetas. Não achando pessoa alguma no ponto de reunião de sua companhia, avistou adiante uma "porção de gente Armada" seguindo para a cidade, às ordens de um "Oficial que parecia ser Espanhol", fardado e em um cavalo branco, o qual ficou sabendo depois ser Bulow. Ao ouvir a multidão dar vivas a Pedro I, desconfiou que "aquele ajuntamento não era lícito e por isso se escondera", partindo em seguida para a casa do capitão Alexandre, na pedreira de São Diogo (no Mangue), a fim de dar parte do acontecido, "por conhecer nele a boa Ordem", e, como este saíra a serviço, retirou-se para casa. ${ }^{52}$ Por fim, a última testemunha, Jorge Mangold, médico, casado, trinta e sete anos, natural da Baviera, morador da Ponte de Manuel Caetano Pinto,

Anos 90, Porto Alegre, v. 11, n. 19/20, p.259-298, jan./dez. 2004 
avisou-o que ouvira barulho de muita gente na rua. Abrindo a janela, deparou-se com uma multidão armada, carregando duas peças de artilharia. Perguntou então a um dos paisanos que supunha puxar as peças o que era aquilo, o qual respondeu, admirado, que "toda a Cidade está tomada a favor de Dom Pedro Primeiro, e nós vamos para lá”. Entre os presentes, notou Bulow, o capitão Lac Hemann, do extinto corpo de Estrangeiros, o tenente José Pinto Duarte da Costa Pereira, o capitão de Veteranos fulano de tal (José Maria de) Sampaio, um criado particular de Antonio de Carvalho, (o capitão Antonio) Pinto Homem, o tenente-coronel Mathias (seu vizinho) e o cadete de Artilharia Montada José Soares (morto no combate). Os manifestantes pararam no alto da ponte e, em altos brados, deram vivas a Pedro I, e, "dizendo que haviam [de] dar a última gota de sangue por ele", seguiram para a cidade, repetindo os mesmos vivas. Afirmou o depoente que, após a partida, recolheu-se em casa e que, ao ouvir o tiroteio, abriu a porta e viu em seguida passar várias pessoas correndo, uma das quais the disse, na fuga, que "estavam perdidos". Mais tarde, soube que os conspiradores pretendiam "pôr o Governo abaixo e aclamarem dom Pedro Primeiro". ${ }^{53}$

Ouvidas as testemunhas, a 2 de maio o juiz do crime da Candelária pronunciou a prisão e livramento os três réus: o barão de Bulow, o coronel Gavião e o administrador da Quinta Miguel Gonçalves dos Santos, sendo a pronúncia sustentada em 22 de junho. ${ }^{54}$ Somente mais de um ano depois, todavia, em 27 de agosto de 1833 , o $1^{\circ}$ Conselho do Júri reuniu-se para julgar a procedência da pronúncia, terminando por achar matéria para a acusação. ${ }^{55}$

Os autos nada mais mencionam acerca dos outros dois réus e contêm apenas a segunda parte da extensa e corajosa defesa feita por Bulow perante o júri em seu julgamento, a 9 de novembro. A defesa é cheia de críticas pessoais e à conduta do promotor Saturnino de Souza e Oliveira e aos jurados, acusados de venais. Como prova da tramóia, diversas falhas processuais foram apontadas pelo réu. Uma delas referia-se à obrigatoriedade estabelecida pelos artigos 262, 263 e 264 do Código do Processo Criminal de se reconvocarem todas as testemunhas ouvidas na formação de culpa para serem novamente 
interrogadas durante o julgamento, o que não teria ocorrido. $\mathrm{Na}$ alegação de Bulow, a dispensa das testemunhas pelos jurados visava prejudicá-lo, pois os depoimentos prestados nessa etapa do processo, embora lhe fossem desfavoráveis, eram bastante contraditórios, evidenciando sua inocência. ${ }^{56}$ Logo, qualquer sentença proferida contra ele seria uma "tirania, filha do espírito de partido, e não da consciência de retos juízes". Bulow lembrava que "a defesa é um direito natural, de que a Lei a ninguém pode privar; é um direito sagrado reconhecido como tal em todos os países civilizados". Depois, passou a atacar mais abertamente os jurados, pois "julgando-os pelas suas opiniões políticas, que devem ser as mesmas, ou iguais às do Sr. Saturnino, visto que ele os nomeou, para ficar certo da minha condenação, vejo-me na dura necessidade de declarar que não acho neste Tribunal Juízes, mas sim acusadores". Nem o juiz de direito que presidia o julgamento escapou dos ataques do réu, que indagava por que ele permitia, ao "Promotor d'encomenda", fazer tudo o que queria: "Será isso por ser ele irmão do Sr. Ministro da Justiça $\mathrm{a}^{[57]}$ ? Receia acaso $V^{a} S^{a}$ a sua suspensão, ou deportação? [...] Desta maneira, Sr. Juiz de Direito, atropelando assim todas as garantias que o Código do Processo faculta aos acusados, eu serei de certo condenado". ${ }^{58}$

Voltando a discutir os pontos da acusação, Bulow questionou a evidência levantada por Saturnino de que ficara provado o crime, ao confessar, em carta por ele assinada, ${ }^{59}$ que redigia $O$ Carijó e estivera na ação de São Cristóvão. Alegava que "só disse, que escrevia para o Carijó, demais, seria necessário provar que fui eu que assinei essa correspondência, quando qualquer podia, como com efeito aconteceu, servir-se do meu nome para me comprometer". Além disso, acusou o promotor de exceder suas funções, ao levantar um fato (a tal carta) "não sujeito a julgação, por isso que não está nos autos, nem as testemunhas dele fazem menção". ${ }^{60}$

Para refutar a afirmação do promotor, de que um estrangeiro não deveria intrometer-se nos assuntos brasileiros, Bulow recorreu de novo a um argumento jurídico fundado no direito natural jusracionalista, tão em voga na época, ${ }^{61}$ defendendo que o

Anos 90, Porto Alegre, v. 11, n. 19/20, p.259-298, jan./dez. 2004 
[...] direito das gentes em todos os países, onde se conhecem e respeitam os seus princípios, assegura aos estrangeiros o gozo inteiro das faculdades naturais, e os direitos universais e imprescritíveis do homem, quais são, a segurança individual, a liberdade, e a participação do benefício e proteção das Leis. ${ }^{62}$

Bulow contestou também a acusação de ter mandado atirar em brasileiros, alegando que sequer ficara provada sua presença na comandante da Guarda Nacional do Sacramento, o tivesse visto no combate; "a não ser que $\mathrm{V}^{\mathrm{a}} \mathrm{S}^{\mathrm{a}}$ se escondesse atrás do seu Rocinante, como Sancho Pança". E aproveitou para recordar, como sempre fazia toda a oposição, o distúrbio exaltado do teatro, quando o então juiz de paz Saturnino "mandou fazer fogo sobre cidadãos desarmados, constituindo-se assim assassino dos seus patrícios". Chamado à ordem pelo juiz, insistiu que não havia desculpa para tal atentado e que o culpado deveria ser acusado de homicídio, terminando por dizer que o "Leão popular" despertará, "e talvez não tarde muito que o Brasil se não vingue de uma Ditadura”. ${ }^{63}$

Seguindo a estratégia de mais atacar do que defender, o réu alegava que não poderia ser julgado, como pretendia o promotor, pelo artigo 87 do Código Criminal, ${ }^{64}$ questionando, como os caramurus, a legalidade do 7 de Abril. Citando o artigo 116 da Constituição, pelo qual Pedro I reinaria sempre no Brasil, e o próprio artigo 87 do Código Criminal, Bulow inquiria o promotor se ainda chamaria os "motores daquela ignominiosa revolta patriotas, e a mim réu, querendo que se me aplique a pena do mesmo Artigo, do qual absolve os outros? [...] Para se legitimar aquele dia nefasto, Sr. Promotor, necessário foi dizer: - $\underline{\text { Calem- }} \underline{\underline{\text { as }}} \underline{\underline{\text { Leis" }}}$. Depois, passou a criticar a Ditadura estabelecida após aquele acontecimento, obrigando o povo a "viver privado de todos os seus direitos, com uma resignação, que não tem exemplo na História". ${ }^{65}$ Daí é que, para ele, teriam surgido os caramurus: "grande parte dos mesmos Cidadãos, [...] vendo o mau rumo que as coisas levavam, puseramse

Anos 90, Porto Alegre, v. 11, n. 19/20, p.259-298, jan./dez. 2004 
de parte com homens que queriam permanecer conseqüentes com os seus princípios, e destes homens se formou o partido hoje chamado - Caramuru". Bulow assumia então toda sua identificação com os caramurus, que "querem a Constituição Jurada sem reformas essenciais, e os Moderados querem reformá-la a seu jeito. A opinião dos primeiros é, a meu ver, mais sensata". Isso porque, para ele, "reformar a Constituição, quer dizer: - constituir de novo a Sociedade, ou - dar-lhe uma nova existência. - Daqui segue-se que o Império está dissolvido, e que o Brasil Constitucional já não existe".

Ao preconizar, como os caramurus, a ilegalidade do 7 de Abril e a preservação incondicional da Constituição de 1824, Bulow expressava um conceito de contrato social e de soberania, tão caro àquele grupo, que via justamente no pacto (e não diretamente no imperador ou no povo) o lugar da soberania, a fonte de todo o poder e da sociedade política e civil. Se a Constituição - outorgada pelo Imperador, mas aprovada pelas câmaras municipais - e o governo de Pedro I - aclamado pelo povo e sancionado pela mesma Carta - eram a expressão desse contrato e, portanto, da soberania, logo a abdicação forçada e a reforma constitucional promovidas, como acreditavam os caramurus, por uma facção que não representava a vontade geral, só poderiam significar um rompimento ilegal desse pacto e um atentado à soberania. Isso representaria uma redefinição arbitrária da organização política e social e, assim, a dissolução do Império, fundado sob tais bases originais. Residem aí as bases do conservadorismo caramuru. ${ }^{66}$

Bulow lembrou também em sua defesa que todos os patriotas implicados na revolta de 3 de abril foram absolvidos pelo júri de acusação (que julgava a procedência da pronúncia), enquanto "eu que não tenho contra mim uma só testemunha, que em Direito me faça culpa, e sendo todo o meu processo nulo, fui julgado com criminalidade". O principal responsável pela sentença, segundo o réu, seria o cônego Januario da Cunha Barboza, "Redator dos Diários de todos os Governos, que tanto influiu para a minha condenação no supracitado Júri", e que, para isso, teria recebido uma comissão de Evaristo da Veiga. Já os jurados de acusação seriam todos amigos

Anos 90, Porto Alegre, v. 11, n. 19/20, p.259-298, jan./dez. 2004 
de Saturnino, de modo que "pouco há a esperar de Vossa integridade". ${ }^{67}$

A seguir, Bulow voltou a negar a autenticidade do manifesto publicado n' $A$ Trombeta com sua assinatura, e até o que ali era dito (e reiterado em seu interrogatório) sobre o coronel Gavião, "a quem nunca falei em minha vida", e o doutor José Cardozo de Meneses (o referido médico C. de M.), cuja "honra e crédito" teriam sido também comprometidos. Na nova versão, bem na linha conspiratória típica da época, o movimento de 17 de abril teria sido "tramado pelos Jacobinos Florestinos, para lhes servir de base para a perdição que intentavam e intentam da Ilustre família dos Andradas, e sobretudo para tirarem da Tutoria o Ex ${ }^{\mathrm{mo}}$. Sr. José Bonifacio". O principal agente da trama seria o delegado e administrador da Quinta Miguel Gonçalves, que teria tido o salário suspenso pelo tutor e reunira a força no pátio do Palácio, mas nunca fora preso, recebendo até dinheiro e passaporte para o Sul como paga. Bulow fazia então vários elogios ao "Patriarca da Independência", em apoio ao "primeiro homem do Brasil". ${ }^{68}$

Por fim, Bulow dizia-se pronto a receber uma "bárbara sentença", por haver "defendido a Liberdade de vossa Pátria", mas certo de ser "absolvido pelo Povo" e ter o apoio de filósofos ilustres (Needham, Harrington, Milton, Fenelon, Locke, Montesquieu, Rousseau, Mably, Condillac, Boulanger, Raynal, Voltaire, Helvecio). ${ }^{69}$ O júri o condenou, em novembro de 1833 , a dez anos de prisão com trabalhos, sentença confirmada pelo Tribunal da Relação. Bulow não pegou então a anistia concedida pelo governo em outubro, mas foi agraciado pelo decreto regencial de 7 de maio seguinte, que comutou a pena em "banimento para fora do Império". ${ }^{70}$

Quanto aos indiciados como cabeças da frente rebelde da Glória, o tenente-coronel Conrado Jacob de Niemeyer (sócio da Sociedade Conservadora) publicou manifesto com sua versão pouco verossímil. Dizia que, estando no Catete com o tenente-coronel Marcos Antonio Bricio às duas horas da manhã de 17 de abril e ouvindo soar as matracas, foram ambos atender ao chamado. No

Anos 90, Porto Alegre, v. 11, n. 19/20, p.259-298, jan./dez. 2004 
caminho, encontraram o capitão Luiz Henriques Tota e o capitãotenente João Leão da Silva Machado, o qual, embora não o conhecesse, perguntou aflito a ele, Niemeyer, sobre João Taylor e contou que uma lancha armada estava estacionada junto à praia da Glória, vinda da fragata Imperatriz, às ordens de Taylor. Percebendo então que fora aquela embarcação o motivo do alarme,

[...] imediatamente resolvemos fazê-la retirar, o que efetuamos, e para nos não comprometermos, para não corrermos risco de vida, resolvermos igualmente seguirmos sós em uma Falua para a Praia Grande, $[\ldots]$ visto que os moderados nos indigitavam como perigosos.

Foi aí que, estando ainda parados próximos à praia da Glória, e sem oferecer resistência, sofreram um ataque de tiros de mosquete, disparados da terra, do qual conseguiram escapar. Mas pouco depois foram os quatro interceptados e presos por duas lanchas do Arsenal de Marinha guarnecidas com permanentes, sendo mais tarde levados para a "espelunca" da Fortaleza da Lage (de onde Niemeyer escreveu o manifesto, a 22 de maio). Este afirmava ainda que era Taylor "o verdadeiro autor de todos os acontecimentos da Glória". Como prova, anexou um bilhete no qual este pedia ao tenente do Estado Maior do Exército Antonio de Saldanha da Gama que procurasse Machado e lhe ordenasse, de sua parte, que, havendo notícia de "movimento popular contra o Governo", embarcasse na falua que o aguardava na Glória e rumasse para a fragata Imperatriz, requisitando então sessenta ou setenta praças armados, que deveriam em seguida desembarcar naquela praia; "porém isto com a maior cautela, e segredo, e eu me acharei à meia noite na praia para o receber com o sinal de uma lanterna". ${ }^{71}$

Mais tarde, a 28 de outubro, Niemeyer, Bricio, Machado e Tota fizeram uma exposição ao público, contendo suas defesas no Conselho de Guerra em 13 de setembro e as sentenças de primeira e segunda instâncias. Diziam que, naquele início de madrugada do

Anos 90, Porto Alegre, v. 11, n. 19/20, p.259-298, jan./dez. 2004 
dia 17, Machado encontrou, no Pocinho da Glória, Tota e Saldanha da Gama, o qual relatou a ordem recebida de Taylor. Machado logo se dispôs a cumpri-la e, em companhia de Tota - que, querendo prestar "Serviço à sua Pátria", ofereceu-se para acompanhá-lo -, dirigiu-se à fragata Imperatriz, onde o comandante Frederico Mariatt (que seria depois sócio-fundador e conselheiro da Sociedade Militar) forneceu os sessenta praças requisitados. Ao retornarem à praia e não vendo a lanterna de Taylor, Machado e Tota decidiram desembarcar à sua procura. Estavam nessa diligência quando, às duas horas, ouviram as matracas e só então encontraram, casualmente, Niemeyer e Bricio, que de nada sabiam, mas que se prontificaram a ajudar, fazendo a lancha retirar-se. ${ }^{72}$

Era essa busca de força armada que se imputava criminosa. Com base no artigo 36 do Código Criminal, ${ }^{73}$ os réus argumentaram que "nenhuma palavra se diz no Processo, que inculque fins sinistros da parte dos Acc. nem força, nem ataque por eles desenvolvido", e que, portanto, o "fato em si não é criminoso". Logo, se havia algum crime, era a traição de Taylor, que dera a ordem para a entrega dos praças, até porque, "segundo o Regulamento Militar nenhum Subalterno deve raciocinar acerca das ordens que recebe". Ademais, as testemunhas - embora "contraditórias, inconcludentes, e suspeitas de parcialidade" - nada haviam dito que incriminasse os acusados; logo, "aonde [se] declara que a força vinha opor-se às ordens do Governo? em nenhum lugar; [...] aonde se indica a menor conivência com os movimentos de S. Cristóvão, ou com qualquer outro lugar? não há tal indicação". A 25 de setembro, o Conselho de Guerra condenou Machado a quatro anos de desterro para fora do Império e inocentou Tota, Bricio e Niemeyer. ${ }^{74}$ Mas, oito dias depois, o Conselho Supremo Militar de Justiça manteve as sentenças de absolvição e reformou as de condenação, isentando de culpa os quatro réus. ${ }^{75}$ Com isso, Bulow acabou sendo o único participante da revolta efetivamente condenado. 
Revoltas regenciais na Corte: o movimento de abril de 1832

\section{Balanço final}

Apurados os fatos, convém fazer um balanço do movimento, tendo como referência as sugestões metodológicas de George Rudé (1991, p.9-10) para o estudo da multidão pré-industrial. Trata-se de analisar as proporções da revolta, as formas de ação, os promotores e líderes, a composição social dos participantes, os alvos ou vítimas, os objetivos e as motivações, as idéias ou crenças que fundamentavam a ação, a eficácia das forças de repressão e as implicações históricas.

A forma de ação consistiu, primeiro, na preparação de duas frentes articuladas de luta: uma na zona sul do Rio de Janeiro, que partiria da Glória para daí tomar o Arsenal de Guerra e possivelmente também o de Marinha, dois pontos militares estratégicos, e outra na zona norte, que partiria de uma mobilização inicial em São Cristóvão para então chegar ao centro da cidade e, a exemplo do 7 de Abril, fazer um pronunciamento decisivo no Campo da Honra, local também estratégico do ponto de vista simbólico. Como ambas as tentativas não deram certo, sendo a primeira abortada ainda nos preparativos pela intervenção militar, só restou, no segundo caso, quando os revoltosos já batiam em retirada, o confronto direto e violento com as forças do governo. Tudo indica que o movimento fora mal organizado, pegando de surpresa muitos dos próprios participantes.

Não obstante o movimento, atingiu proporções bastante consideráveis para a época. Atendo-se apenas ao contingente estimado para o grupo de São Cristóvão (já que faltam dados para avaliar o da Glória), verifica-se que estiveram ali presentes de duzentas e cinqüenta a quatrocentas pessoas. Considerando-se que a cidade do Rio de Janeiro tinha uma população total de cerca de 137.000 habitantes em 1838 (97.000, se descontadas as paróquias rurais) e que a freguesia urbana do Engenho Velho (onde ocorrera o ajuntamento e de onde provinha a grande maioria dos participantes) contava então com somente 8.000 moradores ${ }^{76}$ constata-se que o número de manifestantes corresponderia a algo em torno de 14.000 pessoas nos dias de hoje. ${ }^{77} \mathrm{E}$ isso sem se considerarem aspectos

Anos 90, Porto Alegre, v. 11, n. 19/20, p.259-298, jan./dez. 2004 
fundamentais daquele tempo que dificultavam mobilizações, como o precário sistema de transporte e as contingências da difusão de idéias em uma cultura marcada pela oralidade.

Integravam a mobilização sobretudo empregados de diferentes categorias da Quinta da Boa Vista, militares de várias patentes (especialmente oficiais) do Exército e da Marinha e guardas nacionais do Engenho Velho. Pelos depoimentos das testemunhas inquiridas, verifica-se também o envolvimento de outros grupos sociais, como comerciantes, caixeiros, criados particulares e médicos. Mas tanto as ações judiciais como o noticiário dos jornais limitaram-se a fazer descrições genéricas e vagas dos participantes e a apontar apenas indivíduos conhecidos ou que tiveram papel proeminente na ação. Os demais permaneceram no anonimato, e eram esses que constituíam o grosso da multidão. Mesmo considerando que esses homens, em sua maioria, deviam ser oriundos daquelas categorias sociais, difícil crer que, em meio a tamanha multidão, membros de outras não estivessem presentes, ainda mais que as fontes indicam que a notícia da mobilização em São Cristóvão espalhou-se rapidamente pela região e adjacências, correndo de boca em boca, bem ao estilo das manifestações desse tipo, em uma sociedade marcada pela cultura oral.

Há indícios até do envolvimento de escravos, como Thomé Luiz dos Santos, implicado no processo, sem se falar no relato de um jornal, dizendo que os rebeldes "lançaram mão do triste recurso dos Africanos", para "cansar-nos em um combate, e depois atacarem". ${ }^{78}$ A afirmação é plausível. Afinal, há vários sinais de participação de escravos nos distúrbios de 1831 na Corte, inclusive em uma rebelião planejada pelos próprios criados do Paço de São Cristóvão, abafada às vésperas da Abdicação. ${ }^{79}$ É muito provável que, ao saberem da mobilização na Quinta, escravos e libertos tenham ido até lá, movidos por aspirações de liberdade ou mesmo por mera curiosidade, quando não incitados ou a mando de outras pessoas. As maiores possibilidades de autonomia (sobretudo circulação e comunicação), típicas da escravidão urbana, favoreciam tais ações, ainda mais em uma "cidade-esconderijo" como a Corte,

Anos 90, Porto Alegre, v. 11, n. 19/20, p.259-298, jan./dez. 2004 
onde cativos, libertos e livres confundiam-se facilmente (Chalhoub, 1990, p.212-232). Além disso, em várias regiões escravistas das Américas, no Brasil inclusive, escravos aproveitavam momentos de cisão violenta entre as elites para engajar-se junto àqueles que lhes parecessem possibilitar mais chances de autonomia e liberdade, ainda que tal ação estivesse quase sempre na dependência da iniciativa beligerante de outros grupos, como as facções políticas dissidentes e os militares a elas associados (cf. Berlin et al., s/d, cap.1; Soares, 2001, cap. 5; Carvalho, 1998, cap. 9; Ribeiro, 2002, introd. e cap. 1 e 3; Sousa, 1996, p.68-72).

Quanto aos líderes ou promotores da revolta, a figura central, ao menos na mobilização de São Cristóvão, era a do barão de Bulow. Sobressaíram-se ainda o coronel Antonio Joaquim da Costa Gavião, o administrador da Quinta Miguel Gonçalves dos Santos e, na Glória, o capitão-tenente da Marinha Joaquim Leão da Silva Machado, o capitão do Exército Luis Henriques Tota e os tenentescoronéis Conrado Jacob de Niemeyer e Marcos Antonio Bricio. Talvez se possa incluir o chefe-de-civisão da Marinha João Taylor e o comerciante Antonio de Saldanha, que tiveram atuação importante nos bastidores. É claro, ademais, que o tutor José Bonifacio estava envolvido no caso e, se não participou diretamente da trama ou mesmo a articulou, ao menos deve ter tido conhecimento, logo, sendo conivente. Afinal, a Quinta da Boa Vista foi o principal centro de mobilização, e vários dos subordinados diretos de José Bonifácio e pessoas a ele ligadas (como Bulow) participaram da ação, sem contar suas atitudes suspeitas às vésperas da revolta (negar-se a entregar as peças de artilharia e a transferir o Imperador para o Paço da cidade).

O movimento de 17 de abril, tal como outros da época, teve caráter predominantemente político, o que significa dizer que suas principais motivações e objetivos eram dessa ordem de fatores. É evidente sua tendência caramuru, expressa não só na intenção dos manifestantes de derrubar a Regência ou o ministério, como também nos incessantes vivas dados a Pedro I e aos Andrada, assim como na própria filiação de seus líderes àquela facção. Todavia, é preciso ter

Anos 90, Porto Alegre, v. 11, n. 19/20, p.259-298, jan./dez. 2004 
cautela em taxar o levante de restaurador, aspecto controverso dentro do próprio projeto caramuru, pois, como observou O Independente a propósito das finalidades do movimento, "a própria ambição é que procurava ser satisfeita independentemente de uma restauração, embora se dessem vivas a Pedro $1^{\circ}$, o nome deste Príncipe só servia de atrair todos aqueles, que sempre deram mostras de lhe ter afeição", ou, em outra passagem, "O nome detestado de Pedro $1^{\circ}$, que servia de reunir os conspiradores mascarava todavia planos desconhecidos a todos os instrumentos do partido" ${ }^{80}$ O próprio Bulow admitiu, em seu depoimento, que os vivas a Pedro I concorriam com saudações a Pedro II. Mas nem por isso se devem subestimar os anseios de muitos manifestantes pela volta do ex-imperador; se não fosse assim, seu nome não serviria de apelo para atrair e reunir tanta gente que aderiu ao intento acreditando na Restauração.

Vários fatores contribuíram para a revolta, como o controle do poder pelos moderados e o alijamento, aliado às perseguições, dos grupos de oposição, em particular dos caramurus, afastados de inúmeros cargos públicos e funções honoríficas após a Abdicação, ou impedidos de alcançá-los. Também a insatisfação crescente dos militares, devido aos problemas de perda de prestígio, cortes no efetivo, transferência de unidades, suspensão (ou realização conforme critérios políticos) das promoções, baixas forçadas, prisões de oficiais envolvidos em revoltas, ou mesmo - para os praças - recrutamento forçado, castigos corporais, baixo soldo e rígida disciplina. Havia, ainda, os efeitos da crise econômica, com a alta do custo de vida, a carestia, a alta carga tributária que incidia sobre o comércio urbano, a limitação do crédito e a escassez, falsificação e desvalorização da moeda, problemas que atingiam sobretudo os comerciantes.

À vista desses fatores, não é à-toa que se vêem, entre os manifestantes identificados, militantes caramurus notórios, funcionários do Paço, militares, comerciantes e caixeiros. Nota-se também uma grande presença de portugueses, apontados como habituais simpatizantes de Pedro I e adeptos da Restauração, o que pode bem conotar uma reação ao antilusitanismo, que atingiu seu clímax com a onda de revanchismo e de patriotismo exacerbado

Anos 90, Porto Alegre, v. 11, n. 19/20, p.259-298, jan./dez. 2004 
fomentada após as Noites das Garrafadas e a queda do ex-imperador. Além disso, não deve ser esquecido o papel exercido pela imprensa - não só caramuru, mas também exaltada - na criação de um clima de revolta, que certamente influiu na predisposição para o movimento, quer por meio das críticas contundentes e incessantes feitas ao governo, quer mediante a pregação revolucionária aberta ou velada, quer pela exploração crítica dos problemas acima citados. Há que se considerarem ainda as aspirações de autonomia nutridas por indivíduos de baixa condição social (livres e escravos). Dessa conjunção de fatores é que resultaria o movimento caramuru de 17 de abril.

Se nem todos os rebeldes aderiram à revolta atendendo a claras motivações políticas, muitos outros - provavelmente a maioria assim procederam, até porque a insatisfação militar, a crise econômica, o antilusitanismo e a busca de autonomia tornavam-se evidentemente politizadas. De todo modo, indivíduos com mais educação política e voz nos relatos, como Bulow, fundamentavam o movimento em termos de postulados liberais, como o direito de resistência à tirania e opressão (vendo a Regência como uma ditadura), o rompimento do pacto social e a quebra da soberania (em função da pretensa ilegalidade da Abdicação e das reformas constitucionais). Ainda assim, interesses pessoais de ganho, como a obtenção ou recuperação de cargos e privilégios ou o simples desejo de vingança, devem ter movido vários participantes.

Entre os alvos, visados mas não atingidos, dos rebeldes estavam a tomada dos arsenais de Guerra e Marinha e a queda da Regência. Talvez imaginassem conseguir isso sem grande conflito, como no 7 de Abril (a idéia de ir para o Campo da Honra e ali fazer as exigências já sugere o paralelo). Apesar de Bulow declarar que se planejava matar o regente Lima e Silva, a história não parece crível. Mas o confronto foi inevitável durante a ação, e o alvo dos rebeldes tornouse as forças legalistas das guardas Nacional e Municipal. Entre estas, houve apenas dois mortos e outros dois feridos no combate. Como nas revoltas exaltadas anteriores, o governo foi mais uma vez vitorioso, garantindo, ao menos por enquanto, a supremacia moderada.

Anos 90, Porto Alegre, v. 11, n. 19/20, p.259-298, jan./dez. 2004 


\section{Marcello Basile}

\section{Regency revolts in Court: the movement of April 17, 1832}

Abstract. The regency period (1831-1840) was one of the richest one in terms of political organization, mobilization and debate, as well as the most turbulent in all of Brazil's history. This article analyses one of the main rebellions that happened at that time in Rio de Janeiro's Court in April 17, 1832, headed by the caramurus. This political group arose right after D. Pedro I's resignation and it was composed by politicians and courtiers associated with the former emperor, by old public officers and militaries, and by tradesmen and sales clerks. They opposed to any reform in the Constitution of 1824 , claiming a constitutional monarchy powerfully centralized, such as the First Reign, and even in exceptional cases, stimulating restoration. The movement, in which José Bonifacio was involved, intended to overthrow the ministry or the Regency, and perhaps to claim Pedro I's back. The research sources are newspapers, pamphlets, manifestos and judicial papers.

Keywords: Regency Period. Rio de Janeiro. Rebellion of April 17, 1832.

\section{Notas}

${ }^{1}$ Bons trabalhos a respeito (para só citar uma obra sobre cada revolta) são os de Leitman (1979), Di Paolo (1985), Dias (1995), Souza (1987), e Freitas (1978).

${ }^{2}$ Entre esses movimentos, apenas os de Pernambuco (Setembrada e Novembrada, em 1831; Abrilada, em 1832; e Carneiradas, em 1834-1835) reúnem maior número de estudos: Andrade (1974), especialmente capítulos IV e VI; Barbosa (1996), capítulo IV; e Carvalho (1989), sobretudo capítulos 5 e 6. Para as demais províncias, há somente alguns poucos trabalhos: sobre a revolta de Pinto Madeira e Benze-Cacetes, em 1831-1832, no Ceará, Montenegro (1976); sobre a revolta do Ano da Fumaça, em 1833, em Ouro Preto, Silva (2002), capítulo 7; sobre a chamada Rebelião Cuiabana, em 1834, no Mato Grosso, Corrêa (2000), parte II; e sobre os oito movimentos da Corte, entre 1831 e 1833, Basile (2004), capítulos IX, X, XIII e XIV.

${ }^{3}$ Sobre os projetos moderados, exaltados e caramurus na Corte, cf. Basile (2004), capítulos II, VI, VII e XI, e Morel (1995), capítulo 3. Sobre os exaltados e os caramurus, ver também Basile (2000, 2001).

${ }^{4}$ Segundo a Aurora Fluminense (n. 619, 21.4.1832), principal jornal moderado da Corte, redigido pelo deputado Evaristo da Veiga, "Desde muitos dias se esperava o rompimento dos restauradores: sabia-se que os membros influentes da Sociedade Conservadora não cessavam de trabalhar nesse sentido [...] Era o Governo informado de que na quinta da Boa Vista, onde morava o Tutor do jovem Monarca, havia continuados exercícios militares, em que se adestravam os criados do palácio; que para aquele ponto se chamavam as G. Nacionais da circunvizinhança e que em discursos capciosos se tratava de tornar-lhes odioso o governo existente, e suspirada a época que precedeu a revolução de 7 de Abril". Ver também $O$

Anos 90, Porto Alegre, v. 11, n. 19/20, p.259-298, jan./dez. 2004 
Revoltas regenciais na Corte: o movimento de abril de 1832

Independente, n. 73, de 14.4.1832, e Jornal do Commercio, n. 173, de 6.4.1832. Bonifacio acabou se mudando com o Imperador, no dia 14, para o Paço da Cidade. ${ }^{5}$ Jornal do Commercio, n. 175, de 10.4.1832. Os boatos parecem ter sido maiores do que noticiou o Jornal do Commercio, pois, conforme relatou Aureliano de Souza e Oliveira Coutinho ao ministro da Justiça, Diogo Feijó, teriam os rumores espalhado-se pela cidade nos dias 4, 5 e 6, dando conta de que "vários ajuntamentos de perturbadores do sossego público" estariam se formando não só naquelas localidades indicadas pelo jornal, mas também em Porto do Velho, Magé e outras partes. Segundo o mesmo relato, tais ajuntamentos, contudo, seriam "dos Cidadãos honestos, e sustentadores da ordem, e do Governo legítimo, que com as notícias do dia 3 se puseram em guarda para repelir os inimigos do sossego público" (ibidem, n. $177,21.4 .1832)$.

${ }^{6}$ Cf. Aurora Fluminense, n. 619, de 21.4.1832; O Independente, n. 75, de 21.4.1832; O Homem e a America, n. 28, de 12.5.1832; O Grito da Patria contra os Anarquistas, n. 49, de 25.4.1832; Jornal do Commercio, n. 182, de 18.4.1832; e a circular de 19 de abril do Ministério da Justiça aos presidentes de província, reproduzida no Jornal do Commercio, n. 187, de 26.4.1832.

${ }^{7}$ Salvo outra indicação, as citações nessa descrição advêm das edições de jornal referidas na última nota.

${ }^{8}$ Não por acaso, todos viriam a ser membros da Sociedade Militar, e pelo menos o terceiro era integrante da Sociedade Conservadora da Constituição, associações que congregavam os caramurus na Corte. Sobre essas entidades, cf. Basile (2004), capítulo XII.

${ }^{9} \mathrm{~A}$ Aurora Fluminense indica duzentos e cinqüenta homens (dos quais, "mais de 60 criados"); O Grito da Patria contra os Anarquistas, quatrocentos; o Jornal do Commercio, de trezentos a quatrocentos; o Caramuru (n. 14, de 21.5.1832) admite que o "n. exato não se sabe, que uns dizem ser de 250 indivíduos, outros de 300 , e outros de 400”. Moreira de Azevedo (1875, p. 133) fica com o menor número. ${ }^{10} \mathrm{O}$ chamado barão de Bulow, figura obscura, que, segundo o cônsul geral da Prússia no Brasil, sequer possuía tal título (Aurora Fluminense, n. 611, 30.3.1832), era redator do jornal caramuru O Carijó. Chamava-se Augusto Hugo Auf Hoiser, nasceu em Hanover, Alemanha, em 1797 ou 1798, e naturalizou-se espanhol ao servir como oficial na guarda de corpo de Fernando VII, tendo, ao que parece, participado das lutas liberais de 1820 na Espanha. Pouco antes, teria estado em Nápoles (também palco, naquele ano, de uma revolução liberal), onde se juntou ao séquito do príncipe Saxonia Teschen, pai da rainha daquele reino e da esposa do rei espanhol. Mas, segundo Carl Seidler, seu patrício, o "D. Quixote alemão", acabou expulso da Espanha por dar sumiço em uma sentença de morte contra um conterrâneo. Partiu então para Buenos Aires, onde se meteu nos negócios políticos locais, sendo por isso preso e condenado à forca, mas foi beneficiado com a conversão da pena em deportação perpétua. Daí veio, em data ignorada, para o

Anos 90, Porto Alegre, v. 11, n. 19/20, p.259-298, jan./dez. 2004 


\section{Marcello Basile}

Brasil, passando talvez a integrar (juntamente com Seidler) as tropas alemãs contratadas por Pedro I. O fato é que, logo após a Abdicação, aparecia já como redator d'O Americano, jornal associado aos moderados, e se tornou comandante da Guarda Municipal do Engenho Velho, que participou, a 7 de outubro de 1831, do ataque aos rebeldes exaltados da Ilha das Cobras. Não são conhecidas as causas de seu rompimento com os moderados e o governo, mas é provável que tenha sido uma suposta promessa não cumprida, feita por um dos regentes, de o nomear embaixador do Brasil nos Estados Unidos. Seja o que for, ao se iniciar 1832, já viúvo e dizendo viver de seus bens, aliou-se aos emergentes caramurus, passando a redigir O Carijó. Após ser preso e deportado do Brasil por sua atuação à frente da revolta de 17 de abril, há notícia apenas de que, em 1856, teria comandando com sucesso, partindo da Costa Rica, a reconquista da Nicarágua, invadida um ano antes pelas forças do americano William Walker. Sobre Bulow, ver Autos de sumário contra o barão de Bulow, acusado de participar da conspiração do dia 17 de abril, no Largo do Paço da Quinta da Boa Vista. Rio de Janeiro, 17 de abril de 1832 - 7 de maio de 1834. B. N. - D. Mss. 15, 2, 4, sobretudo p. 3v. de seu interrogatório feito pelo juiz do Crime, e 22 de sua defesa perante o júri. Seidler (1980, p. 327 e 328); Aurora Fluminense, n. 697, de 7.11.1832; Moreira de Azevedo (1884, p. 76-77); Barreto Filho \& Lima (1942, p. 55-56).

${ }^{11}$ As peças estavam na Quinta, e Bonifacio, poucos dias antes, recusara-se a entregálas ao juiz de paz do Engenho Velho (que fora ali averiguar, a mando do governo), alegando que eram antigas e não funcionavam mais.

${ }^{12} \mathrm{O}$ comandante do batalhão do Sacramento era, na verdade, o tenente-coronel Saturnino de Souza e Oliveira, mas, nessa operação, o cargo estava sob a responsabilidade do futuro Duque de Caxias.

${ }^{13}$ O Homem e a America registra dez mortos; o Jornal do Commercio, de doze a quinze; e a Aurora Fluminense, “mais de 20". Moreira de Azevedo, em sua obra a respeito ( p. 135), fala em dez ou vinte.

${ }^{14}$ Cf. Jornal do Commercio, n. 3, de 3.5.1832, e Astréa, n. 827, de 3.5.1832.

15 Cf. Jornal do Commercio, n. 185, de 24.4.1832. A maioria, se não todos, dos oficiais citados foi pouco depois presa, mas houve quem resolvesse justificar-se perante a opinião pública, como o tenente João Manoel Martins Filgueiras, "preso por lhe imputarem ter se achado na rusga que fizeram os Caramurus, roga ao respeitável Público, queira suspender o seu Juízo a respeito da conduta do dito tenente, até que ele apresente com a possível brevidade documentos incontestáveis, e que destroem plenamente a calúnia, pela qual se acha padecendo injustamente" (Diario do Rio de Janeiro, n. 19, de 26.4.1832).

${ }^{16}$ Cf. Diario do Rio de Janeiro, n. 13, de 18.4.1832.

${ }^{17}$ Cf. Diario do Rio de Janeiro, n. 14, de 19.4.1832.

${ }^{18}$ É o caso do missivista do Diario do Rio de Janeiro, O Inimigo de zizanias (possivelmente um dos que se sentiu atingido), que, protestando contra matéria da Aurora Fluminense (n. 619, de 21.4.1832), na qual elogia a ação da Guarda

Anos 90, Porto Alegre, v. 11, n. 19/20, p.259-298, jan./dez. 2004 
Revoltas regenciais na Corte: o movimento de abril de 1832

Nacional mas lança suspeitas sobre parte da $5^{\text {a }}$ companhia de São José (comandada pelo irmão do capitão Luis Henriques Tota, um dos revoltosos da falua da Glória), indagava "se tal asserção é filha da sua moderada lógica, se de uma maldade figadal, ou se, porque um indivíduo de uma companhia é mau, é de jús que todos os seus membros o sejam", ao que conclui, referindo-se ao redator Evaristo da Veiga: "porque então terei a deplorar a sorte da Sociedade Defensora, e dos habitantes da rua dos Pescadores" (Diario do Rio de Janeiro , n. 21, 18 abr. 1832).

${ }^{19}$ A imprensa caramuru celebrou a absolvição dos cinco. Cf. Caramuru, n. 28, 6.10.1832; A Trombeta, n. 50, 27.4.1833; e o panfleto anônimo Os Chimangos em desesperação ou Analise a justa Sentença do Conselho Supremo Militar sobre a justificação do Sr. Taylor (N. L. Vianna, Rio de Janeiro, Typ. do Diario, 1833, p. 1).

${ }^{20}$ Jornal do Commercio, n. 191. $1^{\circ} .5 .1832$ (extrato do Supplemento da Verdade n. 28).

${ }^{21}$ A Trombeta lastimou a condenação, declarando que o júri "se torna prejudicial às públicas liberdades, e favoneia o Despotismo quando, aberrando-se dos princípios de justiça presidem as deliberações deste Tribunal do Povo o espírito de partido, um baixo, e vil servilismo, ou o ignóbil temor de desagradar aos tiranos" (A Trombeta, n. 64, 16.11.1833). O mesmo fizeram o D Pedro I, n. 5, de 20.11.1833, e O Lafuente, n. 1, de 16.11.1833.

${ }^{22}$ Entre outros objetos, foram apreendidos 26 patronas, 10 cinturões com bainha, 30 clavinas, 35 baionetas, 11 talabartes, 38 guarda-fechos, 80 cartuchos embalados, um barril de pólvora, 34 bandeirolas, 296 balas de espingarda e 34 pederneiras. Cf. $A$ Trombeta, n. 191, $1^{\circ} .5 .1832$ (extrato do Supplemento da Verdade n. 28).

${ }^{23}$ Em vista da participação de servidores da Quinta na revolta e das armas ali apreendidas, O Supplemento da Verdade, n. 28, intimava José Bonifacio a esclarecer seu suposto envolvimento, deixando-o, de todo jeito, sem saída: "é muito necessário que o Público saiba se S. Ex. era, ou não sabedor da existência de semelhante barril de pólvora na morada de seu Pupilo: se sabia, é altamente criminoso em consentir: se não sabia, é incapaz de ter a seu cargo objeto tão precioso para o Brasil" (A Trombeta, n. 191, 1.5.1832). Igualmente, O Grito da Patria contra os Anarquistas (n. 49, 25.4.1832) lembrava a recusa do tutor em transferir o imperador para o Paço da Cidade e a entregar as peças de artilharia achadas na Boa Vista, denunciando que o Andrada tivera longas conversas com os empregados do Paço, ordenara a todos aqueles a serviço da Guarda Nacional a se recolherem ali na noite de 16, dispensara o reforço para lá mandado na mesma noite e não consentia que se chamasse Pedro I de ex-imperador, dizendo que este seria o verdadeiro imperador, por ser sagrado e coroado. Sendo verdadeiras tais afirmações, dizia o jornal, "o pobre velho está demente" e "não será difícil de crer-se a sua conivência" com os rebeldes, devendo-se então abrir devassa contra o tutor. O Independente (n. 75, 21.4.1832) fazia a mesma suposição conspiratória contra os Andrada (chamados de Gigantes), sugerindo que agiriam assim por terem sido preteridos

Anos 90, Porto Alegre, v. 11, n. 19/20, p.259-298, jan./dez. 2004 


\section{Marcello Basile}

na escolha dos regentes e que, logo, "devem ser encarados como perigosos inimigos do Governo, que trabalham por derrubar".

${ }^{24}$ Caramuru, n. 14, 21.5.1832, e n.18, 6.6.1832.

${ }^{25}$ A Trombeta Extraordinaria, 4.6.1832. O 7 de Abril não seria, assim, expressão da vontade geral, pois "eu, e todos os homens de senso, não reconhecemos por Nação só o povo do Rio de Janeiro”.

${ }^{26}$ O Carijó, n. 26, 30.6.1832.

${ }^{27}$ Ofício de Faustino Maria de Lima e Fonseca Gutierres, superintendente do Palácio da Quinta da Boa Vista, a João Valentim de Faria Souza Lobato, enviando o resultado da sindicância sobre o tumulto havido naquela quinta, no dia anterior. Rio de Janeiro, 18 de abril de 1832. B. N. - D. Mss. II-34, 16, 43.

${ }_{28}$ Autos de sumário contra o barão de Bulow, acusado de participar da conspiração do dia 17 de abril, no Largo do Paço da Quinta da Boa Vista. Rio de Janeiro, 17 de abril de $1832-7$ de maio de 1834. B. N. - D. Mss. 15, 2, 4, pp. 1 e 1v. O material reunido no códice está desorganizado, havendo cinco partes. A primeira constitui o referido sumário para apurar o movimento de 17 de abril. A segunda contém apenas a segunda parte da defesa do barão de Bulow feita em 1833 perante o júri. A terceira compõe-se de folhas soltas diversas relativas ao mesmo processo. A quarta consiste no sumário aberto a 25 de abril de 1832 pelo juiz do crime do bairro da Candelária, Agostinho Moreira Guerra, também para apurar o movimento. E a quinta refere-se a mais um sumário instaurado a 12 de março de 1832 pelo mesmo juiz do crime contra Bulow, agora por outro problema: resistência à prisão.

${ }^{29}$ Infelizmente, as páginas de verso deste sumário encontram-se praticamente ilegíveis, de modo que apenas partes fragmentadas do interrogatório (e de outras etapas processuais) puderam ser transcritas e analisadas.

${ }^{30}$ Autos de sumário contra o barão de Bulow, doc. cit., p. 2v. e 3 do sumário de 17 de abril.

${ }^{31}$ Ibidem, p. 3v., 4 e 4v.

${ }^{32}$ Ibidem, p. 5, 5v., 6 e $6 \mathrm{v}$.

${ }^{33}$ Ibidem, p. $15 \mathrm{v}, 16$ e $16 \mathrm{v}$.

${ }^{34}$ Ibidem, p. 7, 7v., 8 e $8 \mathrm{v}$.

${ }^{35}$ Ibidem, p. 9 e 9 v.

${ }^{36}$ Ibidem, p. 10, 10v. e 11.

${ }^{37}$ Ibidem, p. 11, 11v., 12, 12v. e 13.

${ }^{38}$ Ibidem, p. $14,14 \mathrm{v}$. e 15.

${ }^{39}$ Ibidem, p. 17, 17v., 18 e $18 \mathrm{v}$.

${ }^{40}$ Ibidem, p.19, 19v., 20 e $20 \mathrm{v}$.

${ }^{41}$ Ibidem, p. 21, 23 e 24.

${ }^{42} \mathrm{O}$ primeiro era acusado de comandar a Infantaria rebelde, o segundo, a Cavalaria e o terceiro, os empregados da Quinta.

Anos 90, Porto Alegre, v. 11, n. 19/20, p.259-298, jan./dez. 2004 
Revoltas regenciais na Corte: o movimento de abril de 1832

${ }^{43}$ Provavelmente, Dom Antonio de Saldanha, o mesmo que agenciou os caixeiros presos que iriam participar do ataque ao Arsenal de Guerra.

${ }^{44}$ Trata-se do processo instaurado em 12 de março de 1832, referido ao final da nota 32 .

${ }^{45}$ Autos de sumário contra o barão de Bulow, doc. cit., p. 3v. a 6 do sumário de 25 de abril.

${ }^{46}$ Ibidem, p. 9-14 (citação, p. 11).

${ }^{47}$ Ibidem, p. 15, 15v. e 16.

${ }^{48}$ Ibidem, p. 16, 16v. e 17.

${ }^{49}$ Cf. ibidem, p. 20, 20v. e 21.

${ }^{50}$ Ibidem, p. 18, 18v. e 19.

${ }^{51}$ Ibidem, p. 19 e $19 \mathrm{v}$.

52 Ibidem, p. 22 a $23 \mathrm{v}$.

${ }^{53}$ Ibidem, p. 23v. a $25 \mathrm{v}$.

${ }^{54}$ Ibidem, p. 26 e 26v.

${ }^{55} \mathrm{O}$ júri era formado por José Antonio Lisboa (presidente), Joaquim Vicente Torres Homem (secretário), Antonio Corrêa Dias de Moura, Alexandre Maria de Carvalho e Oliveira, Antonio José de Araújo, Pedro Bandeira de Gouvêa, Estevão Alves de Magalhães, Simão Bernardino da Costa Passo, José Antonio da Silva Chaves, Manoel Luiz de Castro Filho, Firmino do Nascimento Silva, Joaquim do Valle e Silva, Januario da Cunha Barboza, José Antonio da Camara, Antonio José Felippe, Domingos de Sequeira, Guilherme Jacques Godfroy, Pedro Augusto Nolasco Pereira da Cunha, Lourenço Lopes Pecegueiro, João Thomas de Melo, Manoel Campello e duas pessoas cujos nomes estão ilegíveis. (Autos de sumário contra o barão de Bulow, doc. cit., p. 28 e 28v). Dos vinte e um jurados identificados, ao menos seis eram sócios da Sociedade Defensora (primeiro, segundo, quinto, sétimo, décimo-terceiro e décimo-quinto).

${ }^{56}$ Autos de sumário contra o barão de Bulow, doc. cit., p. 17 da defesa de Bulow perante o júri, cuja segunda parte vai da p. 16 até a $37 \mathrm{v}$.

${ }^{57} \mathrm{O}$ ministro da Justiça, irmão do promotor, era então Aureliano de Souza e Oliveira Coutinho.

${ }^{58}$ Autos de sumário contra o barão de Bulow, doc. cit., pp. 17v. e 18 da defesa perante o júri.

${ }^{59}$ É o manifesto, atrás mencionado, publicado em $A$ Trombeta Extraordinaria de 4.6.1832.

${ }^{60}$ Autos de sumário contra o barão de Bulow, doc. cit., p. $19 \mathrm{v}$. da defesa.

${ }^{61}$ Sobre as escolas jurídicas jusnaturalistas, ver Hespanha (1998, capítulo 7).

${ }^{62}$ Autos de sumário contra o barão de Bulow, doc. cit., p. 21v. da defesa.

${ }^{63}$ Ibidem, p. 22v., 23 e 23v. Sobre esta revolta, ver Basile (2004, cap. IX, seção 2).

${ }^{64}$ “Tentar diretamente e por fatos destronizar o Imperador, privá-lo em todo ou em parte da sua autoridade constitucional, ou alterar a ordem legítima da sucessão" (Tinôco, 2003, p. 160).

Anos 90, Porto Alegre, v. 11, n. 19/20, p.259-298, jan./dez. 2004 


\section{Marcello Basile}

${ }^{65}$ Autos de sumário contra o barão de Bulow, doc. cit., p. 24v. a 26 da defesa.

${ }^{66}$ As diferentes concepções de soberania (do rei, da nação, do povo, em suas correlações com a idéia de pacto social) constituem um aspecto essencial para a compreensão do pensamento e das práticas políticas do período. Exemplo de iniciativa deste tipo é a de Souza (1999, cap. 1).

${ }^{67}$ Autos de sumário contra o barão de Bulow, doc. cit., p. 29v. e 30.

${ }^{68}$ Ibidem, p. 32 a $33 \mathrm{v}$.

${ }^{69}$ Ibidem, p. 37 e $37 \mathrm{v}$.

${ }^{70}$ Ibidem, p. 121 das "folhas diversas". Assinou o decreto o irmão do promotor Saturnino.

${ }^{71}$ NIEMEYER, Conrado Jacob de. Manifesto ao publico. Rio de Janeiro: Typ. do Diario, 1832. p. 3 e 4 (duas últimas citações). Saldanha da Gama cedeu o

${ }^{72}$ NIEMEYER, Conrado Jacob de; BRICIO, Marcos Antonio; MACHADO, Joaquim Leão da Silva; TOTA, Luiz Henriques. Expozição ao publico accompanhada com a defeza, e sentenças do Concelho de Guerra a que responderão os Tenentes Coroneis Conrado Jacob de Niemeyer, Marcos Antonio Bricio; Cappitão Tenente Joaquim Leão da Silva Machado; Cappitão Luiz. Henriques Tota. Pelos accontecimentos, que tiverão documento a Machado, antes de fugir para Buenos Aires. lugar nesta Capital a dezassete de Abil [sic] findo, augmentada Com as Defezas, e Sentenças do primeiro sobre as arguições de ter elevado, em 1825, sem Ordem Joaquim Pinto Madeira de Tenente Coronel, e de ter dezobedecido pertinazmente ás Ordens do Governo; contendo igualmente Os Documentos authenticos, que comprovão as atrocidades com que o Governo se houve para com os individuos mencionados. Rio de Janeiro: Typographia do Diario, 1832. p. 11-14.

73 “Nenhuma presunção, por mais veemente que seja, dará motivo para imposição de pena" (Tinôco, 2003, p. 67).

${ }^{74}$ Este último, todavia, foi condenado a dois meses de prisão em uma fortaleza, não por envolvimento na revolta caramuru, mas pelo crime de desobediência ao governo, por conta de sua insistência em não cumprir a ordem (a pretexto de estar doente) de partir em comissão militar para Santos e nem a de se recolher preso à sua casa para ser submetido à Inspeção de Saúde do Exército (ordem esta dada dois dias antes daquele movimento).

${ }^{75}$ NIEMEYER, Conrado Jacob de; BRICIO, Marcos Antonio; MACHADO, Joaquim Leão da Silva; TOTA, Luiz Henriques, Expozição ao publico..., op. cit., citações p. 15 (três primeiras), 17 (quinta) e 21 (quarta); para as sentenças, ver p. 29-34.

${ }^{76}$ Os números exatos do censo são, respectivamente, 137.078, 97.162 e 8.166. Cf. BRASIL. Directoria Geral de Estatistica. Recenseamento do Brazil realizado em 1 de setembro de 1920. V. I. Rio de Janeiro: Typographia de Estatistica, 1922, p. 426, obra que apresenta um resumo dos censos produzidos até esta data.

${ }^{77}$ O cálculo baseia-se na população da cidade em 2000. de 5.850.544 pessoas, e no percentual de $0,24 \%$ relativo à média de trezentos e vinte e cinco manifestantes,

Anos 90, Porto Alegre, v. 11, n. 19/20, p.259-298, jan./dez. 2004 
Revoltas regenciais na Corte: o movimento de abril de 1832

projetando o mesmo percentual para hoje.

${ }^{78}$ O Grito da Patria contra os Anarquistas, n. 49, de 25.4.1832.

${ }^{79}$ Cf. REBELIÃO DO PAÇO. Processo de encomenda para abafar a Rebelião do Paço que os Creados fizerãm em 1831. Manoel da Paixão criado pretendeu levar alguns escravos p. a rebelião. Quinta da Boa Vista, 29 de março de 1831. B. N. D. Mss. I-28, 21, 19.

${ }^{80} \mathrm{O}$ Independente, n. $75,21.4 .1832$.

\section{Referências}

ANDRADE, Manuel Correia de, Movimentos nativistas em Pernambuco: Setembrizada e Novembrada. Recife: Universidade Federal de Pernambuco, 1974

BARBOSA, Maria do Socorro Ferraz, Liberais \& liberais: guerras civis em Pernambuco no século XIX. Recife: Editora Universitária da Universidade Federal de Pernambuco, 1996.

BARRETO FILHO, Mello; LIMA, Hermeto. História da Polícia do Rio de Janeiro: aspectos da cidade e da vida carioca. Rio de Janeiro: A Noite, 1942. V. II.

BASILE, Marcello Otávio. Os reacionários do Império: a imprensa caramuru no Rio de Janeiro. Dimensões - Revista de História da U.F.E.S., Vitória, Universidade Federal do Espírito Santo - Centro de Ciências Humanas e Naturais, n. 10, jan./jul. 2000. Dossiê escravidão, racismo e exclusão social.

Ezequiel Corrêa dos Santos: um jacobino na Corte imperial. Rio de Janeiro: Fundação Getúlio Vargas, 2001.

O Império em construção: projetos de Brasil e ação política na Corte regencial. 2004. Tese (Doutorado) - I.F.C.S. da Universidade Federal do Rio de Janeiro, Rio de Janeiro, 2004.

BERLIN, Ira; FIELDS, Barbara J.; MILLER, Steven F.; REIDY, Joseph P.; ROWLAND, Leslie S. Slaves no more: three essays on emancipation and the Civil War. Cambridge: Cambridge University Press, s/d.

BRASIL. Directoria Geral de Estatistica. Recenseamento do Brazil realizado em 1 de setembro de 1920. Rio de Janeiro: Typographia de Estatistica, 1922. V. I.

CARVALHO, Marcus Joaquim Maciel de. Hegemony and rebellion in Pernambuco (Brazil), 1821-1835. Urbana: University of Illinois at UrbanaChampaign, 1989.

Anos 90, Porto Alegre, v. 11, n. 19/20, p.259-298, jan./dez. 2004 


\section{Marcello Basile}

CARVALHO, Marcus Joaquim Maciel de. Liberdade: rotinas e rupturas do escravismo no Recife, 1822-1850. Recife: Editora Universitária da Universidade Federal de Pernambuco, 1998.

CHALHOUB, Sidney. Visões da liberdade: uma história das últimas décadas da escravidão na Corte. São Paulo: Companhia das Letras, 1990.

CORRÊA, Valmir Batista. História e violência em Mato Grosso: 1817-1840. Campo Grande: Editora da Universidade Federal de Mato Grosso do Sul, 2000 .

DI PAOLO, Pasquale. Cabanagem: a revolução popular da Amazônia. Belém: Conselho Estadual de Cultura, 1985.

DIAS, Claudete Maria Miranda. Balaios e bem-te-vis: a guerrilha sertaneja. Teresina: Fundação Cultural Monsenhor Chaves, 1995.

FREITAS, Décio. Os guerrilheiros do imperador. Rio de Janeiro: Graal, 1978.

HESPANHA, António Manuel. Panorama histórico da cultura jurídica européia. 2. ed. Lisboa: Europa-América, 1998.

LEITMAN, Spencer. Raízes sócio-econômicas da Guerra dos Farrapos: um capítulo da história do Brasil no século XIX. Rio de Janeiro: Graal, 1979.

MONTENEGRO, João Alfredo de Sousa. Ideologia e conflito no Nordeste rural (Pinto Madeira e a revolução de 1832 no Ceará). Rio de Janeiro: Tempo Brasileiro, 1976.

MOREIRA DE AZEVEDO, Manuel Duarte. Historia patria: o Brazil de 1831 a 1840. Rio de Janeiro: B. L. Garnier, 1884.

Sedição militar na Ilha das Cobras em 1831. Revista do I.H.G.B., Rio de Janeiro, Typ. Imparcial, t. XXXIV, parte 2, 1871.

Os tiros no theatro: motim popular no Rio de Janeiro. Revista do I.H.G.B., Rio de Janeiro, Typ. Imparcial, t. XXXVI, p. 2, 1873.

Sedição militar de julho de 1831 no Rio de Janeiro. Revista do I.H.G.B., Rio de Janeiro, Typ. Imparcial, t. XXXVII, p. 2, 1874.

Motim politico de 3 de abril de 1832 no Rio de Janeiro. Revista do I.H.G.B., Rio de Janeiro, Typ. Imparcial, t. XXXVII, p. 2, 1874.

MOREIRA DE AZEVEDO, Manuel Duarte. Motim politico de 17 de abril de 1832 no Rio de Janeiro. Revista do I.H.G.B., Rio de Janeiro, Typ. Imparcial, t. XXXVIII, p. 2, 1875.

Anos 90, Porto Alegre, v. 11, n. 19/20, p.259-298, jan./dez. 2004 
Revoltas regenciais na Corte: o movimento de abril de 1832

MOREIRA DE AZEVEDO, Manuel Duarte. Motim politico de dezembro de 1833 no Rio de Janeiro: remoção dotutor do imperador. Revista do I.H.G.B., Rio de Janeiro, Typ. Imparcial, t. XXXIX, p. 2, 1876.

Sociedades fundadas no Brazil desde os tempos coloniaes até o começo do actual Reinado. Revista do I.H.G.B., Rio de Janeiro, Typographia de Laemmert, t. XLVIII, p. 2, 1885.

MOREL, Marco. La formation de l'espace publique moderne a Rio de Janeiro (1820-1840): opinion, acteurs et sociabilité. 1995. 2 v. Tese (Doutorado) U.F.R. d'Histoire, Université de Paris I (Pantheon Sorbonne), Paris, 1995.

RIBEIRO, Gladys Sabina. A liberdade em construção: identidade nacional e conflitos antilusitanos no Primeiro Reinado. Rio de Janeiro: Relume Dumará; FAPERJ, 2002.

RUDÉ, George. A multidão na história: estudo dos movimentos populares na França e na Inglaterra, 1730-1848. Rio de Janeiro: Campus, 1991.

SEIDLER, Carl. Dez anos no Brasil. Belo Horizonte; São Paulo: Itatiaia; EDUSP, 1980.

SILVA, Wlamir José da. “Liberais e povo”: a construção da hegemonia liberalmoderada na província de Minas Gerais (1830-1834). 2002. Tese (Doutorado) - I.F.C.S. da Universidade Federal do Rio de Janeiro, Rio de Janeiro, 2002.

SOARES, Carlos Eugênio Líbano. A capoeira escrava e outras tradições rebeldes no Rio de Janeiro (1808-1850). Campinas: Editora da UNICAMP; Centro de Pesquisa em História Social da Cultura, 2001.

SOUSA, Jorge Prata de. Escravidão ou morte: os escravos brasileiros na Guerra do Paraguai. 2. ed. Rio de Janeiro: Mauad; ADESA, 1996.

SOUSA, Octavio Tarquinio de. História dos fundadores do Império do Brasil. Rio de Janeiro: José Olympio, 1957. 10 v.

SOUZA, Iara Lis Franco Schiavinatto Carvalho. Pátria coroada: o Brasil como corpo político autônomo - 1780-1831. São Paulo: UNESP, 1999.

SOUZA, Paulo César. A Sabinada: a revolta separatista da Bahia, 1837. São Paulo: Círculo do Livro, 1987.

TINOCO, Antonio Luiz Ferreira. Codigo criminal do Imperio do Brazil annotado. Brasília: Senado Federal, 2003. Ed. fac-similar da original de 1886.

Anos 90, Porto Alegre, v. 11, n. 19/20, p.259-298, jan./dez. 2004 